\title{
Biosensors for Pesticide Detection: New Trends
}

\author{
Audrey Sassolas ${ }^{1 *}$, Beatriz Prieto-Simón ${ }^{2}$, Jean-Louis Marty ${ }^{1}$ \\ ${ }^{1}$ Laboratoire IMAGES EA 4218, Université de Perpignan via Domitia, \\ Perpignan, France \\ ${ }^{2}$ Nanobioengineering Group, Institute for Bioengineering of Catalonia, \\ Barcelone, Spain \\ Email: *audrey.sassolas@univ-perp.fr
}

Received December 7, 2011; revised February 1, 2012; accepted February 15, 2012

\begin{abstract}
Due to the large amounts of pesticides commonly used and their impact on health, prompt and accurate pesticide analysis is important. This review gives an overview of recent advances and new trends in biosensors for pesticide detection. Optical, electrochemical and piezoelectric biosensors have been reported based on the detection method. In this review biosensors have been classified according to the immobilized biorecognition element: enzymes, cells, antibodies and, more rarely, DNA. The use of tailor-designed biomolecules, such as aptamers and molecularly imprinted polymers, is reviewed. Artificial Neural Networks, that allow the analysis of pesticide mixtures are also presented. Recent advances in the field of nanomaterials merit special mention. The incorporation of nanomaterials provides highly sensitive sensing devices allowing the efficient detection of pesticides.
\end{abstract}

Keywords: Biosensors; Pesticides

\section{Introduction}

In agriculture, farmers use numerous pesticides to protect crops and seeds before and after harvesting. Pesticide is a term used in broad sense for organic toxic compounds used to control insects, bacteria, weeds, nematodes, rodents and other pests. The pesticide residues may enter into the food chain through air, water and soil. They affect ecosystems and cause several health problems to animals and humans. Pesticides can be carcinogenic and cytotoxic. They can produce bone marrow and nerve disorders, infertility, and immunological and respiratory diseases.

Detection of pesticides at the levels established by the Environmental Protection Agency (EPA) remains a challenge. Chromatographic methods coupled to selective detectors have been traditionally used for pesticide analysis due to their sensitivity, reliability and efficiency. Nevertheless, they are time-consuming and laborious, and require expensive equipments and highly-trained technicians. Over the past decade, considerable attention has been given to the development of biosensors for the detection of pesticides as a promising alternative. A biosensor is a self-contained device that integrates an immobilized biological element (e.g. enzyme, DNA probe, antibody) that recognizes the analyte (e.g. enzyme substrate, complementary DNA, antigen) and a transduction

${ }^{*}$ Corresponding author. element used to convert the (bio)chemical signal resulting from the interaction of the analyte with the bioreceptor into an electronic one. According to the signal transduction technique, biosensors are classified into electrochemical, optical, piezoelectric and mechanical biosensors. Electrochemical transducers have been widely used in biosensors for pesticides detection due to their high sensitivity [1-3]. Additionally, their low cost, simple design and small size, make them excellent candidates for the development of portable biosensors [4-8]. According to the biorecognition element, enzymatic, whole cell, immunochemical, and DNA biosensors have been developed for pesticides detection.

This review presents a state-of-the-art update in pesticide biosensors. To clearly report the last advances, biosensors have been classified according to the immobilized recognition element. New trends in the field of pesticide analysis are also reviewed. Aptamers are shown as good candidates to replace the conventional antibodies and, thus, to be the biorecognition elements in more robust and stable biosensors for pesticide detection. Due to exceptional characteristics, molecular imprinted polymers (MIPs) are innovative affinity-based recognition elements that are exploited for the development of environmental sensors. The use of Artificial Neural Networks (ANNs) coupled with a sensor array could substantially improve the selectivity and allow exact identification of pesticides present in a sample. Recent reports on the 
properties of nanomaterials show nanoparticles and nanotubes as promising tools to improve the efficiency of biosensors for the detection of pesticides.

\section{Enzyme Biosensors}

Enzyme biosensors for pesticide detection are based on measurements of enzyme inhibition or on direct measurements of compounds involved in the enzymatic reaction.

\subsection{Inhibition-Based Biosensors}

\subsubsection{Cholinesterase-Based Biosensors}

Enzymatic detection of pesticides is mainly based on cholinesterase (ChE) inhibition [6-10]. Organophosphate and carbamate insecticides are the main ChE inhibitors (Table 1). Other compounds, such as heavy metals, fluoride, nerve gas or nicotine, can also inhibit ChE enzyme. Although this lack of selectivity, ChE-based biosensors are shown as powerful tools when a rapid toxicity screening is required.

\subsubsection{Mono-Enzymatic Biosensors}

Two types of natural ChE enzymes are known: acetylcholinesterase (AChE) and butyrylcholinesterase (BChE). These enzymes have different substrates: AChE preferentially hydrolyzes acetyl esters, such as acetylcholine (Equation (1)), whereas BChE hydrolyzes butyrylcholine (Equation (2)):

$$
\begin{aligned}
& \text { Acetylcholine }+\mathrm{H}_{2} \mathrm{O} \stackrel{\text { AChE }}{\longrightarrow} \text { Choline }+ \text { Acetic acid } \\
& \text { Butyrylcholine }+\mathrm{H}_{2} \mathrm{O} \stackrel{\text { BChE }}{\longrightarrow} \text { Choline + Butyric acid }
\end{aligned}
$$

The $\mathrm{pH}$ variation produced by the acid formation can be measured using electrochemical methods, such as potentiometry [11]. This $\mathrm{pH}$ change can also be measured using $\mathrm{pH}$-sensitive spectrophotometric indicators [12,13] or $\mathrm{pH}$ sensitive fluorescence indicators [14].

Artificial substrates, acetylthiocholine for AChE and butyrylthiocholine for BChE, have been also used. The enzymatic hydrolysis of these substrates produces electroactive thiocholine (Equations (3) and (4)).

$$
\begin{aligned}
& \text { Acetylthiocholine }+\mathrm{H}_{2} \mathrm{O} \\
& \stackrel{\text { AChE }}{\longrightarrow} \text { Thiocholine }+ \text { Acetic acid } \\
& \text { Butyrylthiocholine }+\mathrm{H}_{2} \mathrm{O} \\
& \stackrel{\text { aChE }}{\longrightarrow} \text { Thiocholine }+ \text { Butyric acid } \\
& 2 \text { Thiocholine }+\mathrm{H}_{2} \mathrm{O} \\
& \underset{\text { oxidation }}{\stackrel{\text { Anodic }}{\longrightarrow} \text { Dithiobischoline }+2 \mathrm{H}^{+}+2 \mathrm{e}^{-}}
\end{aligned}
$$

This system has two advantages over the bi-enzymatic ChE/ChOD biosensors. First, it has a simpler design. Secondly, the detection potential is lower than the one used for the oxidation of $\mathrm{H}_{2} \mathrm{O}_{2}$.
La Rosa et al. proposed the use of 4-aminophenyl acetate as alternative ChE substrate $[15,16]$. They oxidize the enzymatic product 4-aminophenol at $+250 \mathrm{mV}$ vs SCE. Electrochemical biosensors for pesticide detection based on the use of this substrate avoid interferences from the oxidation of other electroactive compounds [1518]. However, 4-aminophenyl acetate is not commercially available and its use involves a laborious and timeconsuming synthesis. Moreover, this substrate is unstable and requires special storage conditions (nitrogen atmosphere, below $0^{\circ} \mathrm{C}$ ).

\subsubsection{Bi-Enzymatic Biosensors}

In most cases, ChE is coupled to choline oxidase (ChOD) [6]. AChE hydrolyzes its natural substrate to choline and acetic acid (Equation (1)). Since choline is not electrochemically active, ChOD is used to produce $\mathrm{H}_{2} \mathrm{O}_{2}$, which can be oxidized onto the platinum electrode at around + $0.7 \mathrm{~V}$ vs Ag/AgCl (Equations (7) and (8)). However, an over-potential is required, favouring the oxidation of interfering electroactive species present in real samples. To overcome this drawback, different approaches have been proposed, such as the use of nanomaterial-modified electrodes. A biosensor for the detection of pesticides and nerve agents was developed by immobilizing AChE and ChOD onto Au-Pt bimetallic NPs [19]. The synergistic effect of these nanoparticles increased the surface area and facilitated the electron transfer process, reducing the applied potential for the detection of $\mathrm{H}_{2} \mathrm{O}_{2}$. Alternatively to $\mathrm{H}_{2} \mathrm{O}_{2}$ oxidation, $\mathrm{ChE}$ inhibition can be followed using a Clark electrode able to measure the oxygen consumed by the ChOD catalyzed reaction (Equations (6)-(8)) [20].

$$
\begin{aligned}
& \text { Acetylcholine }+\mathrm{H}_{2} \mathrm{O} \stackrel{\text { AChE }}{\longrightarrow} \text { Choline }+ \text { Acetic acid } \\
& \text { Choline }+\mathrm{O}_{2} \stackrel{\text { ChoD }}{\longrightarrow} \text { Betaine }+\mathrm{H}_{2} \mathrm{O} \\
& \mathrm{H}_{2} \mathrm{O} \underset{\mathbf{v s ~} \mathbf{A g} / \mathbf{A g C l}}{\longrightarrow} \mathrm{O}_{2}+2 \mathrm{H}^{+}+2 \mathrm{e}^{-} \\
& \mathrm{O}_{2}+4 \mathrm{H}^{+}+4 \mathrm{e}^{-} \underset{\text { vs Ag/ } / \mathbf{A g C l}}{\longrightarrow} \mathrm{H}_{2} \mathrm{O}
\end{aligned}
$$

AChE was also coupled to tyrosinase [18]. In this case, AChE enzymatic hydrolysis of phenyl acetate produces phenol compounds, characterized by a high oxidation potential. For this reason, tyrosinase enzyme was used to convert the phenol to quinone, compound that can be electrochemically reduced to catechol at $-150 \mathrm{mV}$ vs $\mathrm{Ag} / \mathrm{AgCl}$.

\subsubsection{Tri-Enzymatic Biosensors}

Peroxidase may be added to the bi-enzyme system to develop a tri-enzymatic biosensor. Karousos et al. used a Quartz Crystal Microbalance (QCM) sensor based on three enzymes for the determination of organophosphorus and 
Table 1. Characteristics of electrochemical cholinesterase-based biosensors for pesticide detection.

\begin{tabular}{|c|c|c|c|c|c|c|}
\hline Target analyte & $\begin{array}{l}\text { Detection } \\
\text { technique }\end{array}$ & $\begin{array}{c}\text { Enzyme immobilization } \\
\text { technique }\end{array}$ & Electroactive materials & Linearity range (M) & $\begin{array}{l}\text { Detection } \\
\text { limit (M) }\end{array}$ & References \\
\hline \multicolumn{7}{|c|}{ Organophosphorus insecticides } \\
\hline Chloropyrifos & $\mathrm{CV}$ & Covalent binding & $\begin{array}{l}\text { Exfoliated graphite } \\
\text { nanoplatelets }\end{array}$ & ND & $1.58 \times 10^{-10}$ & {$[170]$} \\
\hline Chloropyrifos & SWV & Cross-linking & SWCNT & $10^{-11}-10^{-6}$ & $10^{-12}$ & {$[171]$} \\
\hline Chloropyrifos & Amperometry & Covalence & ZnS NPs & $1.5 \times 10^{-9}-4 \times 10^{-8}$ & ND & {$[172]$} \\
\hline Chlorpyrifos oxon & $\mathrm{CV}$ & Entrapment & PEDOT:PSS & ND & $4 \times 10^{-9}$ & {$[173]$} \\
\hline Chlorpyrifos oxon & Amperometry & Entrapment & $\begin{array}{l}\text { 7,7,8,8-tetracyano } \\
\text { quinodimethane }\end{array}$ & $6 \times 10^{-9}-2.4 \times 10^{-9}$ & $6 \times 10^{-9}$ & {$[174,175]$} \\
\hline Paraoxon & Amperometry & Affinity & MWCNT & $3.6 \times 10^{-14}-3.6 \times 10^{-11}$ & $5 \times 10^{-15}$ & {$[176]$} \\
\hline Paraoxon & Fluorescence & Adsorption & CdTe QDs & & & \\
\hline Paraoxon & Amperometry & Entrapment & - & $1.3 \times 10^{-7}-5 \times 10^{-6} \mathrm{M}$ & $3.5 \times 10^{-2}$ & {$[177]$} \\
\hline Paraoxon & Amperometry & Adsorption & $\begin{array}{l}\text { AuNPs, grapheme oxide } \\
\text { nanosheets }\end{array}$ & ND & $10^{-13}$ & {$[178]$} \\
\hline Paraoxon & Amperometry & Cross-linking & CoPc-Prussian blue & $7.3 \times 10^{-9}-1.8 \times 10^{-8}$ & $7.3 \times 10^{-9}$ & {$[179]$} \\
\hline Methylparaoxon & Amperometry & Entrapment & $\mathrm{CoPc}$ & $2 \times 10^{-9}-4 \times 10^{-6}$ & $2.6 \times 10^{-9}$ & {$[180]$} \\
\hline Methylparaoxon & Amperometry & Affinity & MWCNT & $3.8 \times 10^{-14}-3.8 \times 10^{-11}$ & $5.3 \times 10^{-15}$ & {$[176]$} \\
\hline Triazophos & Amperometry & Adsorption & MWCNT & $3 \times 10^{-8}-7.8 \times 10^{-6}$ & $10^{-8}$ & {$[181]$} \\
\hline Dichlorvos & Amperometry & Adsorption & - & ND & $10^{-10}$ & {$[182]$} \\
\hline Dichlorvos & Amperometry & Entrapment & $\mathrm{CoPc}$ & ND & $7 \times 10^{-12}$ & {$[23]$} \\
\hline Dichlorvos & Amperometry & Entrapment & $\mathrm{CoPc}$ & $2 \times 10^{-10}-10^{-8}$ & $9.6 \times 10^{-11}$ & {$[180]$} \\
\hline Dichlorvos & Amperometry & Adsorption & - & Up to $10^{-16}$ & $10^{-17}$ & {$[183]$} \\
\hline Dichlorvos & \multirow{4}{*}{ Amperometry } & \multirow{4}{*}{ Cross-linking } & \multirow{4}{*}{ Prussian blue } & $4.52 \times 10^{-11}-4.52 \times 10^{-8}$ & $1.13 \times 10^{-11}$ & \multirow{4}{*}[184]{} \\
\hline Omethoate & & & & $2.34 \times 10^{-10}-4.69 \times 10^{-8}$ & $7.04 \times 10^{-11}$ & \\
\hline Trichlorfon & & & & $1.16 \times 10^{-10}-1.94 \times 10^{-8}$ & $1.94 \times 10^{-11}$ & \\
\hline Phoxim & & & & $1.68 \times 10^{-10}-3.35 \times 10^{-8}$ & $3.35 \times 10^{-11}$ & \\
\hline Trichlorfon & Amperometry & Adsorption & $\mathrm{TiO}_{2}$ and $\mathrm{PbO}_{2}$ particles & $10^{-8}-2 \times 10^{-5}$ & $10^{-10}$ & {$[185]$} \\
\hline Monocrotophos & Amperometry & Adsorption & AuNPs & $4.5 \times 10^{-9}-4.5 \times 10^{-6}$ & $2.7 \times 10^{-9}$ & {$[186]$} \\
\hline Monocrotophos & Amperometry & Covalent binding & AuNPs-QDs & $4.5 \times 10^{-9}-4.5 \times 10^{-6}$ & $1.3 \times 10^{-9}$ & {$[155]$} \\
\hline Acephate & FET & Affinity & CNT & ND & $5.45 \times 10^{-14}$ & {$[187]$} \\
\hline Dimethoate & Amperometry & Adsorption & $\begin{array}{l}\text { CNTs, zirconia NPs, } \mathrm{Au} \\
\text { colloid coated } \mathrm{Fe}_{3} \mathrm{O}_{4} \text { magnetic } \\
\text { NPs, prussian blue }\end{array}$ & $4.4 \times 10^{-6}-4.4 \times 10^{-2}$ & $2.4 \times 10^{-6}$ & {$[188]$} \\
\hline \multicolumn{7}{|c|}{ Carbamate insecticides } \\
\hline Aldicarb & Amperometry & Cross-linking & CoPc-Prussian blue & $6.3 \times 10^{-8}-1.6 \times 10^{-7}$ & $1.3 \times 10^{-7}$ & {$[179]$} \\
\hline Carbaryl & Amperometry & Adsorption & - & $2.5 \times 10^{-8}-5 \times 10^{-7}$ & $1.5 \times 10^{-8}$ & {$[189]$} \\
\hline Carbaryl & Amperometry & Covalent binding & QDs & $5 \times 10^{-9}-2.5 \times 10^{-7}$ & $3 \times 10^{-9}$ & {$[155]$} \\
\hline Carbaryl & Amperometry & Cross-linking & CoPc-Prussian blue & $1.2 \times 10^{-7}-4.9 \times 10^{-7}$ & $1.2 \times 10^{-7}$ & {$[179]$} \\
\hline Carbaryl & Amperometry & Adsorption & MWCNT & $5 \times 10^{-13}-5 \times 10^{-10}$ & $5 \times 10^{-15}$ & {$[190]$} \\
\hline Carbaryl & Amperometry & Entrapment & $\mathrm{CoPc}$ & $9 \times 10^{-8}-4 \times 10^{-6}$ & $1.6 \times 10^{-7}$ & {$[180]$} \\
\hline Carbofuran & $\mathrm{DPV}$ & Adsorption & CNTs-AuNPs & $4.8 \times 10^{-9}-9 \times 10^{-8}$ & $4 \times 10^{-8}$ & {$[191]$} \\
\hline Carbofuran & Amperometry & Cross-linking & $\mathrm{CoPc}$ & $10^{-10}-10^{-7}$ & $4.9 \times 10^{-10}$ & {$[192]$} \\
\hline Carbofuran & Amperometry & Entrapment & CoPc & $4 \times 10^{-9}-8 \times 10^{-8}$ & $4.5 \times 10^{-9}$ & {$[180]$} \\
\hline
\end{tabular}


carbamate pesticides [21]. Acetylcholine was converted to choline by AChE and then, choline was converted to hydrogen peroxide by choline oxidase. In the presence of HRP, $\mathrm{H}_{2} \mathrm{O}_{2}$ oxidized 3,3'-diaminobenzidine to an insoluble product that precipitated out and adsorbed on the crystal surface causing a decrease in the resonant frequency of the crystal. AChE inhibition caused by pesticides reduced the amount of QCM-detectable precipitate produced. This QCM-enzyme sensor system allowed detecting carbaryl and dicholorvos concentrations down to $1 \mathrm{ppm}$.

\subsubsection{ChE Sources}

The enzyme source has an important effect on the biosensor performance. Several AChE enzymes are available from different sources, such as Electric eel, Bovine or Human erythrocytes, Horse serum and Human blood. Generally, ChE enzymes isolated from insects are more sensitive than those extracted from other sources. The use of recombinant $\mathrm{ChE}$ enzymes also allows improvements on the sensitivity of biosensors [22]. As an example, Valdes-Ramirez and co-workers compared the use of three AChEs in biosensors for the detection of dichlorovos in a sample of apple skin [23]. The use of genetically modified AChE decreased four orders of magnitude the detection limit found for the use of AChE from wild type Drosophila melanogaster and Electriceel.

\subsubsection{Tyrosinase-Based Biosensors}

Tyrosinase oxidizes monophenols in two consecutive steps: first, the enzyme catalyzes the o-hydroxylation of monophenol to o-diphenol (cresolate activity, Equation (9)) which, in a second step, is oxidized to its corresponding o-quinone (catecholase activity, Equation (10)):

$$
\begin{aligned}
& \text { Monophenol }+\mathrm{O}_{2} \stackrel{\text { Cresolate activity }}{\longrightarrow} \text { Catechol } \\
& \text { Catechol }+\mathrm{O}_{2} \underset{-0.2 \mathrm{~V} \mathrm{vs} \mathrm{Ag} / \mathrm{AgCl}}{\stackrel{\text { Catecholase activity }}{\rightleftarrows}} \text { O-quinone }
\end{aligned}
$$

Tyrosinase is inhibited by different compounds, such as carbamate pesticides and atrazine. Numerous electrochemical biosensors based on the inhibition of tyrosinase activity have been reported [24-29] (Table 2).

Tyrosinase biosensors suffer from poor specificity since many substrates and inhibitors can interfere. The enzyme is inherently unstable, reducing the lifetime of the tyrosinase-based biosensors. However, tyrosinase can stand high temperatures and the organic solvents used to dissolve the pesticides.

\subsubsection{Alkaline Phosphatase (ALP)-Based Biosensors} Alkaline phosphatase catalyses the following reaction:

Phosphate monoester $+\mathrm{H}_{2} \mathrm{O} \rightarrow$ alcohol + phosphate (11)

ALP is inhibited by different compounds. Several ALPbased biosensors for the detection of pesticides have

\begin{tabular}{|c|c|c|c|c|c|c|}
\hline Target analyte & $\begin{array}{l}\text { Detection } \\
\text { technique }\end{array}$ & $\begin{array}{c}\text { Enzyme immobilization } \\
\text { technique }\end{array}$ & Electroactive materials & Linearity range (M) & $\begin{array}{l}\text { Detection } \\
\text { limit (M) }\end{array}$ & References \\
\hline \multicolumn{7}{|c|}{ Organophosphorus insecticides } \\
\hline Methyl parathion & Amperometry & Cross-linking & $\mathrm{CoPc}$ & $2.28 \times 10^{-8}-3.8 \times 10^{-7}$ & ND & [26] \\
\hline Diazinon & Amperometry & Cross-linking & $\mathrm{CoPc}$ & $6.24 \times 10^{-8}-1.64 \times 10^{-7}$ & ND & {$[26]$} \\
\hline Dichlorvos & Amperometry & Cross-linking + entrapment & $\begin{array}{l}\text { 1,2-naphthoquinone-4-sulfonate } \\
\text { (NQS) }\end{array}$ & Up to $8 \times 10^{-6}$ & $6 \times 10^{-8}$ & {$[25]$} \\
\hline Dimethoate & \multirow{4}{*}{ Amperometry } & \multirow{4}{*}{ Adsorption } & \multirow{4}{*}{ - } & $2 \times 10^{-6}-2 \times 10^{-1}$ & $10^{-6}$ & \multirow{4}{*}{ [29] } \\
\hline Pirimicarb & & & & $2 \times 10^{-5}-5 \times 10^{-3}$ & $10^{-5}$ & \\
\hline Paraoxon & & & & $10^{-5}-10^{-2}$ & $5 \times 10^{-6}$ & \\
\hline Malathion & & & & $10^{-5}-10^{-2}$ & $5 \times 10^{-6}$ & \\
\hline \multicolumn{7}{|c|}{ Carbamate insecticides } \\
\hline Carbofuran & Amperometry & Cross-linking & $\mathrm{CoPc}$ & $2.26 \times 10^{-8}-4.07 \times 10^{-7}$ & ND & {$[26]$} \\
\hline Carbofuran & & & & $10^{-5}-10^{-2}$ & $5 \times 10^{-6}$ & [29] \\
\hline Aldicarb & Amperometry & Adsorption & - & $10^{-5}-10^{-2}$ & $5 \times 10^{-6}$ & [29] \\
\hline Carbaryl & & & & $10^{-5}-10^{-2}$ & $5 \times 10^{-6}$ & [29] \\
\hline Carbaryl & Amperometry & Cross-linking & $\mathrm{CoPc}$ & $4.97 \times 10^{-8}-2.48 \times 10^{-7}$ & ND & {$[26]$} \\
\hline Thiodicarb & $\begin{array}{c}\text { Square Wave } \\
\text { Voltammetry } \\
(\mathrm{SWV})\end{array}$ & Entrapment & - & $3.75 \times 10^{-7}-2.23 \times 10^{-6}$ & $1.58 \times 10^{-7}$ & {$[24]$} \\
\hline
\end{tabular}

Table 2. Characteristics of electrochemical inhibition-based biosensors using tyrosinase for pesticide detection. 
been developed using different enzyme substrates depending on the transduction method.

Ayyagari et al. described a chemiluminescent ALPbased biosensor for the detection of paraoxon [30]. The biosensor was based on the measurement of the intensity of the light generated by ALP-catalyzed dephosphorylation of a chemiluminescent substrate, chloro 3-(4-methoxy spiro [1,2-dioxetane-3-2'-tricyclo-[3.3.1.1]-decan]-4yl) phenyl phosphate.

A fluorescent ALP-based biosensor for the detection of organochlorine, pesticides (carbamate and fenitrothion), heavy metals and $\mathrm{CN}^{-}$was also described [31]. ALP enzyme catalyzed the hydrolysis of 1-naphthyl phosphate to fluorescent 1-naphthol.

Mazzei and co-workers developed electrochemical ALP-based biosensors for the detection of malathion and 2,4-dichlorophenoxyacetic acid (2,4-D) by using 3-indoxyl phosphate, phenyl phosphate or ascorbate-2phosphate as enzyme substrates [32]. Another electrochemical ALP-based biosensor was also described for the screening of several environmental pollutants. The biosensor was based on the entrapment of ALP in a hybrid sol-gel/chitosan film, deposited on the surface of a screen-printed electrode [33]. The substrate ascorbic acid 2-phosphate was catalyzed by the enyme to produce ascorbic acid, which was monitored by amperometry.

\subsubsection{Peroxidase-Based Biosensors}

Peroxidase molecules can be first oxidized by $\mathrm{H}_{2} \mathrm{O}_{2}$ and then reduced by phenolic compounds. This process involves two enzyme intermediates: compounds I and II (Figure 1). Phenolic compounds are thus oxidized to quinones or free radical products, able to be electrochemically reduced on the electrode surface. Several organic and inorganic compounds have been reported to inhibit the enzyme activity of peroxidase by coordinating compound I. A biosensor based on the inhibition of peroxidase was described for the detection of thiodicarb, a carbamate pesticide [34]. HRP was covalently bound on a gold electrode. In the presence of hydrogen peroxide, hydroquinone was oxidized by peroxidase to p-benzoquinone which could be electrochemically reduced to hydroquinone at a potential of $-0.072 \mathrm{~V}$ vs $\mathrm{Ag} / \mathrm{AgCl}$. The presence of inhibitor compounds induced a decrease of the biosensor current response.

\subsubsection{Acid Phosphatase}

Acid phosphatase (AP) is reversibly inhibited by some pesticides. AP has been used with glucose oxidase (GOD) to develop a bienzymatic biosensor for the electrochemical detection of Malathion, methyl parathion and paraoxon [37]. Both enzymes were coupled on a commercial $\mathrm{H}_{2} \mathrm{O}_{2}$ sensing electrode. This system is based on the following reactions:

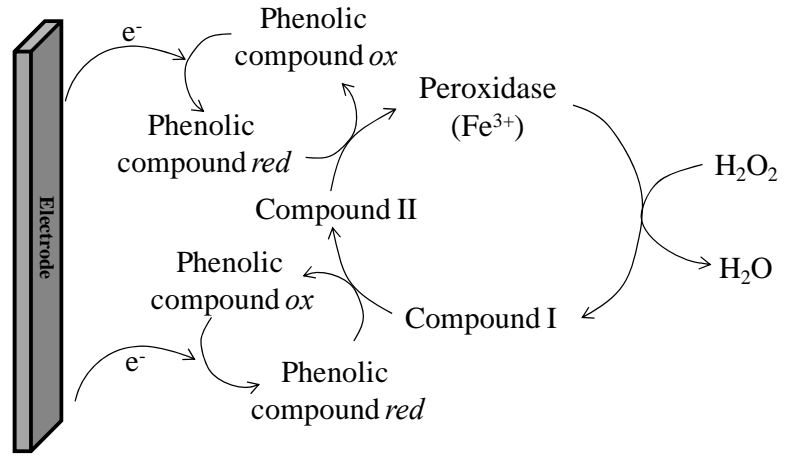

Figure 1. Scheme of the reactions occurring at the surface of a peroxidase-modified electrode. ox: oxidized form, red: reduced form $[35,36]$.

$$
\begin{aligned}
& \text { Glucose }-6 \text { - phosphate }+\mathrm{H}_{2} \mathrm{O} \\
& \stackrel{\text { AP }}{\longrightarrow} \text { Glucose }+ \text { inorganic phosphate }
\end{aligned}
$$

Glucose $+\mathrm{O}_{2} \stackrel{\text { GOD }}{\longrightarrow}$ Gluconolactone $+\mathrm{H}_{2} \mathrm{O}$

\subsection{Catalytic Biosensors}

\subsubsection{Organophosphorus Hydrolase (OPH)}

$\mathrm{OPH}$ is an enzyme that hydrolyzes organophosphorus pesticides [38], such as parathion, methyl parathion [39] or paraoxon $[40,41]$. This enzyme hydrolyzes P-O, P-S and P-CN bonds generating two protons, able to be electrochemically detected, and an alcohol, which in many cases is chromophoric and/or electroactive.

However, these biosensors show lower sensitivity values and higher detection limits than cholinesterase-based biosensors. Moreover, they can only detect some organophosphorus (OP) compounds.

Table 3 summarizes the performances of some $\mathrm{OPH}-$ based biosensors reported in the literature.

\subsubsection{Glutathion-S-Transferase}

Glutathion-S-transferase (GST) was used to develop a fiber-optic biosensor for the detection of atrazine [42]. The enzyme was immobilized by cross-linking on a membrane that was supported on an inner glass disk by means of an intermediate binder sol-gel layer. Bromcresol green was incorparated in the sol-gel as $\mathrm{pH}$ indicator. GST catalyzed the nucleophile attack of GSH on atrazine, releasing $\mathrm{H}^{+}$. This $\mathrm{pH}$ variation was optically measured by colour changes of bromcresol green.

\section{Whole Cell Biosensors}

\subsection{Microbial Biosensors}

To develop a microbial biosensor, microorganisms have to be immobilized onto a transducer using different chemical (e.g. cross-linking) or physical techniques (e.g. entrapment) [43]. Microorganisms have several advantages 
Table 3. Characteristics of hydrolase-based biosensors.

\begin{tabular}{|c|c|c|c|c|c|c|}
\hline Target analyte & $\begin{array}{l}\text { Detection } \\
\text { technique }\end{array}$ & $\begin{array}{c}\text { Enzyme immobilization } \\
\text { technique }\end{array}$ & $\begin{array}{l}\text { Electroactive } \\
\text { materials }\end{array}$ & Linearity range (M) & $\begin{array}{l}\text { Detection } \\
\text { limit (M) }\end{array}$ & References \\
\hline Paraoxon & Amperometry & Covalent binding & SWCNT & $5 \times 10^{-7}-8.5 \times 10^{-6}$ & $10^{-8}$ & {$[41]$} \\
\hline Paraoxon & Amperometry & Entrapment & Mesoporous carbon & $2 \times 10^{-7}-8 \times 10^{-6}$ & $1.2 \times 10^{-7}$ & {$[40]$} \\
\hline Paraoxon & Amperometry & Entrapment & MCNT & Up to $4 \times 10^{-6}$ & $15 \times 10^{-8}$ & [194] \\
\hline Paraoxon & Amperometry & Cross-linking & MWNT & $5 \times 10^{-7}-2 \times 10^{-6}$ & $0.314 \times 10^{-6}$ & [195] \\
\hline Paraoxon & Optic & Cross-linking & - & $10^{-5}-4.8 \times 10^{-4}$ & $2 \times 10^{-6}$ & [196] \\
\hline Ethyl Parathion & Amperometry & Covalent binding & - & ND & $<3.4 \times 10^{-9}$ & [197] \\
\hline Methyl parathion & Amperometry & Covalent binding & AuNPs - MWCN-QDs & $1.9 \times 10^{-8}-7.6 \times 10^{-7}$ & $3.8 \times 10^{-9}$ & [39] \\
\hline Methyl parathion & Amperometry & Entrapment & MCNT & Up to $2 \times 10^{-6}$ & $8 \times 10^{-7}$ & [194] \\
\hline Parathion & Optic & Cross-linking & - & $10^{-5}-2 \times 10^{-4}$ & $2 \times 10^{-6}$ & [196] \\
\hline Paraoxon & Fluorescence & Affinity & - & $10^{-6}-8 \times 10^{-4}$ & ND & [198] \\
\hline $\begin{array}{c}\text { Diisopropyl } \\
\text { phosphorofluoridate } \\
\text { (DFP) }\end{array}$ & Fluorescence & Affinity & - & $2 \times 10^{-6}-4 \times 10^{-4}$ & ND & [198] \\
\hline
\end{tabular}

as sensing elements in the development of biosensors. They are able to metabolise a wide range of chemical compounds. The use of whole cells, as a source of intracellular enzymes, avoids expensive protocols of enzyme purification. The enzyme is maintained in its natural environment improving its stability and activity. The main limitation of the use of whole cells is the diffusion of substrate and products through the cell wall resulting in a slow response as compared to enzyme-based biosensors. To overcome this drawback, cells can be permeabilised [44].

\subsubsection{Electrochemical Microbial Biosensors}

\subsubsection{Amperometric Detection}

Amperometric microbial biosensors have been widely developed for the determination of biochemical oxygen demand (BOD) in order to measure biodegradable organic pollutants in aqueous samples. Most of BOD biosensors consist of a microbial film sandwiched between a porous cellulose membrane and a gas-permeable membrane. Organic substrates, present in wastewater samples, diffuse through the dialysis membrane and are assimilated by the immobilized microbial population, increasing the bacterial respiration rate. Therefore, less dissolved oxygen diffuses through the gas-permeable Teflon membrane to be detected by a Clark oxygen electrode [45]. Different microbial strains were used as biosensing element such as Arxula adeninivorans [46], Bacillus subtilis [47], Serratia marcescens [48] or yeast [49]. Single microorganisms metabolize a limited range of organic pollutants, which may result in an inaccurate estimation of BOD values. To overcome this problem, mixed cultures (e.g. Bacillus subtilis and Trichosporon cutaneum [50]) or activated sludges [51] were used.
Mulchandani's group developed amperometric microbial biosensors for the determination of organophosphate pesticides with p-nitrophenyl substituent (e.g. paraoxon, methyl parathion, parathion, fenitrothion and ethyl pnitrophenol thiobenzenephosphonate (EPN)) [52]. These biosensors were based on the co-immobilization of microorganisms and $\mathrm{OPH}$ (free or expressed on the cell surface of other microorganisms). OPH hydrolyzes the pesticide and releases p-nitrophenol. Released p-nitrophenol can be oxidized by some microorganisms, such as or Pseudomonas putida JS444. Two detection strategies were used:

- OPH hydrolyzes the organophosphorus compounds to produce p-nitrophenol. Released p-nitrophenol was degraded by some bacteria, such as Pseudomonas putida JS444. This degradation resulted in electroactive compounds, amperometrically detected [53,54].

- The degradation of p-nitrophenol by some microbes, such as Arthrobacter sp. JS443, consumes oxygen. A Clark oxygen electrode was used to measure oxygen concentration changes [55-57].

\subsubsection{Potentiometric Detection}

Conventional potentiometric microbial biosensors have been developed using ion-selective electrodes (e.g. $\mathrm{pH}$, ammonium) or gas sensing electrodes (e.g. $\mathrm{pCO}_{2}$ ) coated with an immobilized microbial layer. Assimilation of substrates by microbes causes changes in potential due to ion accumulation or depletion [43].

A potentiometric biosensor for the direct detection of paraoxon was based on the immobilization of recombinant $E$. Coli on a glass $\mathrm{pH}$ electrode. Bacteria was engineered to contain the opd gene that encodes the OPH enzyme [58]. Entrapped OPH-active bacteria hydrolyzed 
OP compounds producing two protons. The quantity of released $\mathrm{H}^{+}$was correlated to the concentration of hydrolyzed paraoxon.

\subsubsection{Optical Microbial Biosensors}

Optical microbial biosensors allowing the detection of pollutants such as phenols and heavy metals have been developed [52,59]. However, only few optical microbial biosensors allowing the detection of pesticides have been reported. A disposable colorimetric microbial biosensor for the detection of methyl parathion pesticide was described [60]. Whole cells of Flavobacterium sp. were immobilized on a glass fiber filter paper. The OPH activity of Flavobacterium sp. hydrolyzed methyl parathion into p-nitrophenol that can be detected at $410 \mathrm{~nm}$.

\subsection{Plant Tissue and Photosynthesis-Based Biosensors}

\subsubsection{Plant Tissue-Based Biosensors}

The use of plant tissue is an attractive alternative to enzymatic biosensors. Tissue that acts as enzyme source presents many advantages [61]:

- High stability and activity resulting from the maintenance of the enzyme in its natural environment;

- Long lifetime of biosensors;

- High reproducibility of the experimental results;

- Availability and low price of a wide range of plant tissues;

- Avoidance of tedious and time-consuming enzyme extraction and purification steps;

- Presence of the required cofactors in the used tissue. Planktonic algae have been widely used to develop biosensors for pollutants present in the aquatic ecosystems. Biosensors based on immobilized Chlorella vulgaris microalgae were reported [62-64]. Those biosensors were based on the inhibition of enzymes located on the external membrane, such as alkaline phosphatases and esterases, by heavy metals and pesticides.

\subsubsection{Photosynthesis-Based Biosensors}

Different types of photosynthetic materials were used as recognition element for the development of biosensors: whole cells (e.g. microalgae), chloroplasts or thylakoids and photosystem II (PS II) [65]. PS II is a supramolecular pigment-protein complex located in the thylakoid membrane. It catalyzes the light-induced transfer of electrons from water to plastoquinone in a process that evolved oxygen. The activity of PS II can be inhibited by several groups of herbicides and heavy metals [66].

The measurement of oxygen evolution using a Clarktype electrode is a standard procedure for the determination of the photosynthetic activity $[61,67,68]$. The incorporation of several types of photosystem II specific arti- ficial electron acceptors as electroactive mediators allows to maximize the photosynthetic activity. Other biosensors are not based on the use of a Clark-type electrode. In these cases, alga were immobilized on the surface of ITO electrode [69] or SPE [70].

Optical photosynthesis-based biosensors have also been described based on the fluorescence induced by chlorophyll $a$. The light absorbed by chlorophyll molecules of PSII may be assimilated into the light reactions of the photosynthesis or may be released as fluorescence or thermal energy. Herbicides inhibit photosynthetic electron flow by blocking the PSII quinone binding site causing an increase in the chlorophyll fluorescence emission. Based on this principle, herbicide biosensors based on the measurement of the algal chlorophyll fluorescence at $682 \mathrm{~nm}$ (under $469 \mathrm{~nm}$ excitation light) were developed [71-73]. Recently, three microalgae species (Dictyosphaerium chlorelloides, Scenedesmus intermedius and Scenedesmus sp.) were entrapped within a silica matrix and the increase in the amount of chlorophyll fluorescence signal was used to quantify simazine [74].

\section{Immunosensors}

Immunosensors are characterized by the highly selective affinity interactions between immobilized antibodies (Ab) or antigens (Ag), on the transducer surface, and their specific analytes, Ag or Ab respectively [75-77]. Unlike enzyme-based biosensors, able to evaluate total toxicity, immunosensors are specific for a molecule.

Several immunosensors for pesticides detection have been described, based on electrochemical, optical, piezoelectric and mechanical transduction methods.

\subsection{Electrochemical Immunosensors}

Table 4 presents performance characteristics of some electrochemical immunosensors.

\subsubsection{Amperometric Detection}

Numerous amperometric immunosensors for the detection of pesticides have been reported [78-81]. A simple amperometric immunosensor was developed for the analysis of 2,4-D in the presence of organic solvents, required to solubilize it from soil [81]. An amperometric immunosensor based on a carbon paste SPE incorporateing a conducting polyaniline (PANI)/poly(vinylsulphonic acid) (PVS) copolymer was developed for the detection of atrazine [82]. Free and HRP-labeled atrazine competed for their binding to the Ab previously immobilized onto the PANI-PVS-modified electrode surface. The addition of HRP substrate, hydrogen peroxide, enabled the catalytic reaction inducing a flow of electrons from the electrode surface through the molecular wires of the PANI/PVS copolymer. 
Table 4. Characteristics of some electrochemical immunosensors.

\begin{tabular}{|c|c|c|c|c|c|}
\hline Target analyte & Immobilization technique & Electroactive materials & Linearity range (M) & Detection limit (M) & References \\
\hline \multicolumn{6}{|c|}{ Amperometry } \\
\hline Phenanthrene (PAH) & $\begin{array}{c}\text { Adsorption of } \\
\text { BSA-phenanthrene conjugate }\end{array}$ & - & $2.8 \times 10^{-9}-2.5 \times 10^{-7}$ & $4.5 \times 10^{-9}$ & [199] \\
\hline Paraoxon & Adsorption + Nafion film & AuNPs & $8.7 \times 10^{-8}-6.9 \times 10^{-6}$ & $4.4 \times 10^{-8}$ & [200] \\
\hline Atrazine & Affinity & - & $7 \times 10^{-10}-1.35 \times 10^{-8}$ & $1.7 \times 10^{-10}$ & [201] \\
\hline Atrazine & Adsorption & PANI-PVS copolymer & $5.5 \times 10^{-10}-2.3 \times 10^{-8}$ & $4.6 \times 10^{-10}$ & [82] \\
\hline $17-\beta$ estradiol & $\begin{array}{l}\text { Adsorption of BSA-estradiol } \\
\text { conjugate }\end{array}$ & - & $2.2 \times 10^{-12}-3.6 \times 10^{-5}$ & $9.2 \times 10^{-13}$ & [202] \\
\hline Pichloram & $\begin{array}{l}\text { Adsorption of BSA-pichloram } \\
\text { conjugate }\end{array}$ & Gold nanoclusters & $3.6 \times 10^{-9}-3.6 \times 10^{-5}$ & $1.8 \times 10^{-9}$ & [203] \\
\hline Diuron & $\begin{array}{l}\text { Adsoprtion of hapten-BSA } \\
\text { conjugate }\end{array}$ & Prussian blue, AuNPs & $4.3 \times 10^{-12}-4.3 \times 10^{-5}$ & $4.3 \times 10^{-12}$ & [156] \\
\hline Naphthalene & Adsorption & AuNPs & $3.9 \times 10^{-9}-7.8 \times 10^{-7}$ & $6.2 \times 10^{-10}$ & [204] \\
\hline \multicolumn{6}{|c|}{ Impedance spectroscopy } \\
\hline Atrazine & Affinity & - & $4.6 \times 10^{-8}-1.4 \times 10^{-6}$ & $9.3 \times 10^{-8}$ & [97] \\
\hline Atrazine & $\begin{array}{l}\text { Adsorption of BSA-atrazine } \\
\text { conjugate }\end{array}$ & - & ND & $2.7 \times 10^{-8}$ & [90] \\
\hline Atrazine & $\begin{array}{l}\text { Adsorption of BSA-atrazine } \\
\text { conjugate }\end{array}$ & - & ND & $3.9 \times 10^{-8}$ & [91] \\
\hline Atrazine & $\begin{array}{l}\text { Covalent immobilization of } \\
\text { BSA-atrazine conjugate }\end{array}$ & - & ND & $1.9 \times 10^{-10}$ & [92] \\
\hline Atrazine & Affinity & - & $4.6 \times 10^{-10}-4.6 \times 10^{-6}$ & $4.6 \times 10^{-11}$ & [93] \\
\hline Atrazine & Affinity/entrapment & - & $4.6 \times 10^{-10}-9.3 \times 10^{-7}$ & $4.6 \times 10^{-10}$ & [94] \\
\hline 2,4-D & Covalent binding & - & $2 \times 10^{-10}-2 \times 10^{-6}$ & ND & [205] \\
\hline
\end{tabular}

\subsubsection{Conductometric Detection}

To our knowledge, only a few conductometric immunosensors for environmental analysis have been described, probably due to their low specificity.

Valera and co-workers used this method for atrazine detection [83-85]. Atrazine was covalently immobilized on interdigitated $\mu$-electrodes (ID $\mu \mathrm{E})$ [85]. Detection of free atrazin was achieved through a competitive reaction with immobilized atrazine for the antibody added in solution. The detection method was based on the use of antibodies labeled with gold nanoparticles. Their presence amplified the conductive signal. This biosensor is adapted for the detection of atrazine in red wines since none matrix effect related to red wine samples were observed.

\subsubsection{Potentiometric Detection}

A few potentiometric immunosensors have been described for environmental analysis [86-88]. A potentiometric biosensor was developed for terbuthylazine (TBA), a herbicide widely used in agriculture [88]. Free TBA and immobilized TBA-BSA conjugate competed for their binding to urease-labeled specific Ab. The addition of urease substrate, urea, enabled the potentiometric measurement of the ammonia produced in an inversely proportional amount of the TBA present in the sample.

\subsubsection{Electrochemical Impedance Spectroscopy}

Several impedimetric immunosensors for the detection of pesticides have been reported [89-97]. The electron transfer resistance at the interface between the electrode and the solution changes slightly when the immobilized biomolecule binds the analyte. Impedance spectroscopy allows a label-free detection with many potential advantages, such as higher signal-to noise ratio, ease of detection, lower assay cost, faster assays and shorter analysis times. However, regeneration of the sensing surface is typically time-consuming and not reproducible [4].

Table 4 presents characteristics of some impedimetric immunosensors for pesticide analysis.

Valera and co-workers developed biosensors for atrazine detection using a competitive immunoassay. AtrazineBSA conjugate was immobilized on the ID $\mu \mathrm{E}$ surface, either by adsorption [90,91] or by covalent binding [92]. Best performances were obtained when the conjugate was covalently bound to the ID $\mu \mathrm{E}$ area previously activated with (3-glycidoxypropyl)trimethoxysilane. The detection limit was $1.9 \times 10^{-10} \mathrm{M}$. Recently, an impedimet- 
ric immunosensor for atrazine detection was developed by immobilizing anti-atrazine antibody modified with histidine-tag onto a polypyrrole (PPy) film $\mathrm{N}$-substituted by nitrilotriacetic acid (NTA) electrogenerated on a gold electrode [93]. After coordination of $\mathrm{Cu}^{2+}$ to poly-NTA, anchoring of histidine-tagged atrazine was achieved by affinity interactions between histidine groups and the chelated $\mathrm{Cu}^{2+}$ centers. In the presence of atrazine, the interaction of the analyte with the immobilized antibody triggered an increase of the charge transfer resistance proportional to the pesticide concentration. The detection limit was $4.6 \times 10^{-11} \mathrm{M}$.

\subsection{Optical Immunosensors}

Optical immunosensors are based on the measurement of changes in the optical characteristics induced by the formation of Ab-Ag complexes.

\subsubsection{SPR}

SPR-based biosensors have been reported for the detection of different pesticides (Table 5). SPR allows realtime monitoring and does not require labeled molecules [98].

Mauriz and co-workers used a commercial SPR (SENSIA) for the on-line monitoring of pesticides in real water samples [99-104]. Pesticides-BSA conjugates were immobilized through a self-assembled monolayer (SAM) onto a gold electrode to obtain a reusable sensing surface. The same sensing surface was used for more than 200 assays, showing good reproducibility. Several conjugates were immobilized on the sensing surface of one individual flow cell to simultaneously detect DTT, chlorpyrifos and carbaryl.

Miura and co-workers developed a SPR-based immunosensor for the competitive detection of 2,4-D [105108]. A 2,4-D-ovalbumine conjugate was immobilized onto the Au surface of the sensor chip to compete with free 2,4-D for their selective binding to monoclonal anti2,4-D. Amplification through avidin-biotin interactions was described to enhance the sensitivity of the sensor. The amplification was based on successive incubations with a biotinylated secondary antibody against anti-2,4-D, avidin and finally biotin-BSA molecules. The sensor signal was amplified by a factor of 10 [108].

\subsubsection{Fluorescence Polarisation}

Immunospecies have to be conjugated to fluorescent labels (e.g. cyanine) to develop immunosensors. However, fluorescent organic dyes suffer from a photo-bleaching problem. This drawback can be overcome by the use of nanoparticles as fluorescent reporters. For this purpose, europium chelate-dyed polystyrene NPs have been used to develop immunosensors for the detection of atrazine [109].

\subsubsection{Total Internal Reflection Fluorescence (TIRF)}

TIRF was used to develop immunosensors for water pollution control [75,110-115]. Barzen et al. described a prototype of a portable TIRF-based immunosensor combined with a flow injection system to monitor surface

Table 5. Characteristics of some SPR-based immunosensors.

\begin{tabular}{|c|c|c|c|c|}
\hline Target & Immobilization technique & Linearity range (M) & Detection limit (M) & References \\
\hline DTT & Covalent binding & $1.7 \times 10^{-10}-5 \times 10^{-9}$ & $5.64 \times 10^{-11}$ & {$[104]$} \\
\hline 2,4-D & Adsorption of 2,4-D—BSA conjugate & $2.3 \times 10^{-9}-4.5 \times 10^{-6}$ & $2.3 \times 10^{-9}$ & {$[107]$} \\
\hline 2,4-D & Adsorption of 2,4-D—ovalbumin conjugate & $4.5 \times 10^{-10}-1.4 \times 10^{-6}$ & $4.5 \times 10^{-10}$ & [106] \\
\hline 2,4-D & Covalent immobilization of 2,4-D—BSA conjugate & ND & $3.6 \times 10^{-11}$ & [108] \\
\hline 2,4-D & Covalent immobilization of 2,4-D—BSA conjugate & $4.5 \times 10^{-10}$ & $4.5 \times 10^{-10}$ & [105] \\
\hline Chorpyrifos & Covalent binding & $6.6 \times 10^{-10}-1.4 \times 10^{-7}$ & $1.4 \times 10^{-10}$ & [104] \\
\hline Carbaryl & Covalent binding & $8.2 \times 10^{-9}-7.3 \times 10^{-8}$ & $4.5 \times 10^{-9}$ & [104] \\
\hline Isoproturon & Covalent binding & $6.3 \times 10^{-9}-7.9 \times 10^{-8}$ & $4.8 \times 10^{-10}$ & {$[206]$} \\
\hline Atrazine & Covalent immobilization of atrazine—BSA conjugate & $1.3 \times 10^{-10}-3.7 \times 10^{-9}$ & $9.3 \times 10^{-11}$ & [99] \\
\hline TNT & Adsorption of TNP-BSA conjugate & $2.6 \times 10^{-11}-1.3 \times 10^{-6}$ & $2.6 \times 10^{-11}$ & [207] \\
\hline TNT & Covalent immobilization on AuNPs & ND & $4.4 \times 10^{-11}$ & [208] \\
\hline TNT & Covalent binding & $3.5 \times 10^{-11}-1.3 \times 10^{-7}$ & ND & [209] \\
\hline TNT & Covalent binding & Up to $3.1 \times 10^{-8}$ & $4.8 \times 10^{-10}$ & {$[210]$} \\
\hline 2,4-dinitrotoluene & Covalent binding & $4.4 \times 10^{-9}-4.4 \times 10^{-7}$ & $8.8 \times 10^{-11}$ & [211] \\
\hline 2,4-dichlorophenol & Affinity (protein G) & ND & $1.2 \times 10^{-7}$ & {$[212]$} \\
\hline
\end{tabular}


water quality [111]. Aminodextran-analyte conjugates were adsorbed onto the transducer surface. Specific antibodies labeled with a fluorophore were incubated with the target analytes present in the sample. Then, free labeled-antibodies bound immobilized analyte derivatives. A collimated laser beam $(635 \mathrm{~nm})$ coupled to the transducer was guided by total internal reflection causing excitation of the bound fluorescent antibody in the evanescent field (Figure 2). This TIRF-based immunosensor, called the RIver ANAlyser (RIANA), was used to monitor the levels of atrazine, simazine and alachlor in the Ebre Delta and the estuarine area of Portugal [77]. Studies were focused on the evaluation of matrix effects, interferences due to the presence of crossreactant substances and on the validation of the sensor. Results show the efficiency of the RIANA immunosensor for monitoring natural waters in compliance with the Drinking Water Directive of the European Union.

Automated Water Analyser Computer Supported System (AWACSS) was developed using the same principle as RIANA immunosensor. However, improvements were made in three critical areas: 1) expanded multi-analyte analysis capability allowing for simultaneous detection of up to 30 analytes; 2) novel design approaches to the optical detection and fluidics including miniaturized integrated optics and micro-fluidics and 3) intelligent remote surveillance and control for unattended continuous monitoring [116].

\subsubsection{Polarisation-Modulation InfraRed Reflection-Absorption Spectroscopy (PM-IRRAS)}

Reflection-absorption IR spectroscopy combined with polarization modulation was proposed as a novel optical transduction mode. Recently, PM-IRRAS was used to develop immunosensors allowing the detection of environmental pollutants [117-119].

This principle was applied by Pradier and co-workers to determine atrazine using an indirect competitive format [119]. First, sensor chips were coated with ovalbumine-atrazine derivatives. The surfaces were analyzed by
PM-IRRAS and the integrated area of the peptide bands was measured. Then, the different steps of the conventional ELISA test were performed. Successive binding of anti-atrazine antibody and secondary anti-rabbit immunoglobulin $G$ antibody resulted in a change of the IR absorption properties of the organic film at the sensor surface. Detection of atrazine was based on the analysis of the amide I and II bands. When the concentration of free pesticide increased, the intensity of amide bands decreased.

\subsection{Piezoelectric Immunosensors}

Piezoelectric immunosensors are devices based on materials such as quartz crystals with $\mathrm{Ab}$ or Ag immobilized on their surface. A QCM sensor is a mass-sensitive device able to measure very small mass changes. Several QCM immunosensors for environmental monitoring have been described [120], but only few of them were developed for the detection of pesticides. A QCM immunosensor was developed for the analysis of carbaryl, and 3,5,6-trichloro-2-pyridinol (TCP), the main metabolite of the insecticide chlorpyrifos and of the herbicide triclopyr [121]. The biosensor was based on the immobilization of hapten conjugates onto the gold electrode via SAM. This covalent immobilization allowed the reusability of the modified electrode surface for at least 150 assays without significant loss of sensitivity.

\subsection{Mechanical Immunosensors}

Microcantilever sensors are based on a response due to either surface stress variation or mass loading. Interaction between an immobilized ligand (e.g. antibody) and an analyte (e.g. an antigen) causes a surface stress change of the cantilever and can be detected as changes in the cantilever deflection. Microcanlitever sensors offer many advantages: label-free detection, high precision, reliability, reduced size and easy manufacture of multielement sensor arrays [122].

Some microcantilever immunosensors have been developed for the detection of pesticides such as atrazine

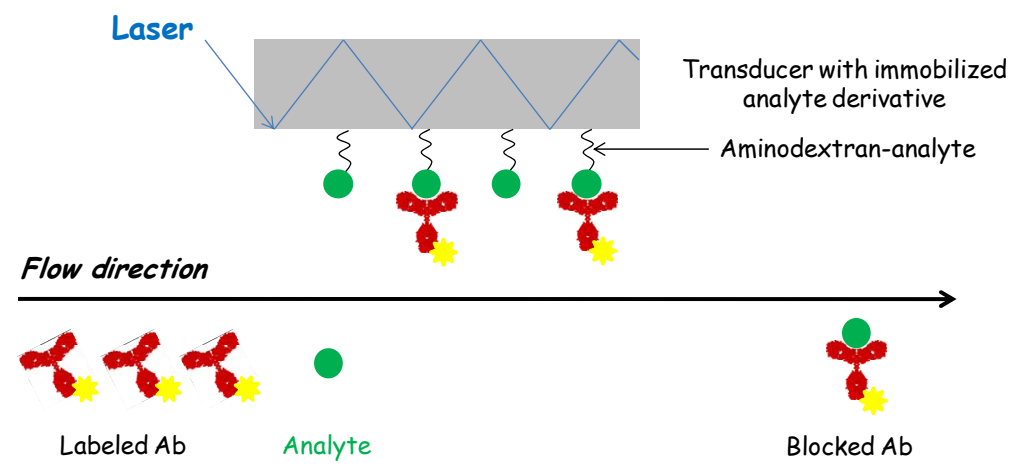

Figure 2. Principle of a TIRF-based immunosensor [111]. 
[123,124], DDT [125] and 2,4-D [123]. Suri et al. developed an ultrasensitive cantilever-based immunosensor for the detection of atrazine. A thiolated atrazine antibody was immobilized on a gold coated cantilever. The binding of atrazine to the immobilized $\mathrm{Ab}$ changes the surface stress causing bending of the cantilever. The detection limit was 1 ppt (4.65 pM). Recently, a cantilever-based competitive immunosensor was developed for the detection of 2,6 dichlorobenzamide (BAM), which is the most frequent found pesticide residue in European groundwater [126].

\section{DNA Biosensors}

DNA biosensors exploit the preferential binding of complementary single-stranded nucleic acid sequences. They usually rely on the immobilization of a single-stranded DNA probe onto a surface able to recognize its complementary DNA target sequence by hybridization [122].

Recently, an electrochemical DNA biosensor was developed to study DNA damage caused by several pesticides, such as atrazine, 2,4-D, glufosinate ammonium, carbofuran, paraoxon-ethyl and difluorobenzuron [127]. A biotinylated DNA probe was immobilized on a streptavidin-modified electrode surface. This DNA probe was hybridized with biotinylated complementary DNA target analyte. Streptavidin labeled with ferrocene was further attached to the hybridized biotinylated DNA. The close proximity of ferrocene to the electrode surface induced a current signal. The presence of pesticides caused an unwinding of the DNA and thus a decrease of the ferrocene oxidation current observed in voltammetric experiments. Paraoxon-ethyl and atrazine caused the fastest and most severe damage to DNA.

\section{New Trends}

\subsection{Aptamers}

In 1990, Ellington's group [128], Gold's group and Robertson's group independently reported the development of an in vitro selection technique which allowed the discovery of specific nucleic acid sequences that bind non-nucleic acid targets with high affinity and specificity. The technique was called SELEX (Selection Evolution of Ligands by EXponential enrichment) and the resulting DNA or RNA oligonucleotides are referred to as aptamers [129-131].

Aptamers show high affinity towards a wide range of target analytes, including proteins, metal ions and pathogenic microorganisms. Aptamers possess several competitive advantages over antibodies, such as their accurate and reproducible chemical production [132]. Immunization and animals hosts are not necessary to produce aptamers. The selected nucleic acids bind their targets with affinity and specificity comparable to those of antibodies. Aptamers are more stable than antibodies. They can be selected in extreme conditions whereas antibodies are only stable in physiological conditions. Aptamers can also undergo reversible denaturation and they can be easily modified with new functional groups without affecting their activity. Due to its many advantages, numerous aptamer-based biosensors have been developed for the detection of a wide range of targets [133-137].

To our knowledge, few aptamers for the detection of pesticides have been selected. Recently, a DNA aptamer specific for acetamiprid was described [138]. The potential of aptamers for the pesticide detection has not still been exploited but aptamer-based biosensors could be an alternative to the conventional methods of pesticide analysis.

\subsection{Molecularly Imprinted Polymers (MIPs)}

Molecular imprinting, which allows the formation of specific recognition sites in polymers, is used to develop MIP-based sensors in the areas of environmental, food and pharmaceutical analysis [139].

The overall principle of molecular imprinting is presented in Figure 3. The template interacts with functional monomers either by the formation of covalent bonds or by self-association. Then, these monomers are polymerized around the template with the help of a crosslinker in the presence of a porogenic solvent. Template molecules are removed by extensive washing steps to disrupt the interactions between the template and the monomers. This process allows to obtain synthetic polymers possessing specific cavities complementary to the template in size, shape and position of the functional group $[140,141]$. The choice of the chemical reagents making up the MIP must be judicious in order to create highly specific cavities designed for the template molecule.

MIPs have been used as artificial recognition elements of biosensors for pesticide detection. An optical sensor for the detection of pesticides (chloropyrifos, diazinon and glyphosate) was developed by forming MIP onto optical fibers [142]. In this case, a luminescent lanthanide (europium), used as spectroscopic probe, was incorporated into the polymer. Detection of the analyte was based upon the changes that occur in the lanthanide spectrum when pesticide was incorporated to $\mathrm{Eu}^{3+}$. The increase of the pesticide concentration induced an increase in the luminescence intensity of the spectra. Several electrochemical MIP-based sensors have been described [143-145]. An electrochemical sensor for 2,4-D was developed by electropolymerization of polypyrrole on a glassy carbon electrode in the presence of template 2,4-D molecules. During the electropolymerization step, 

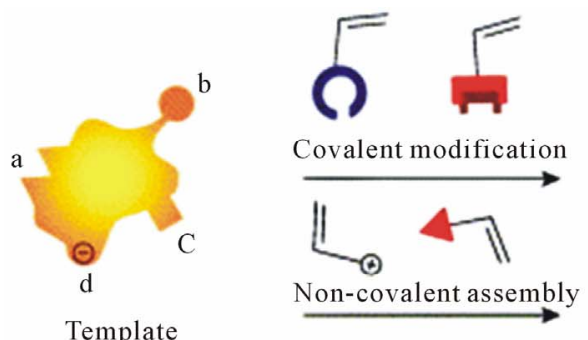
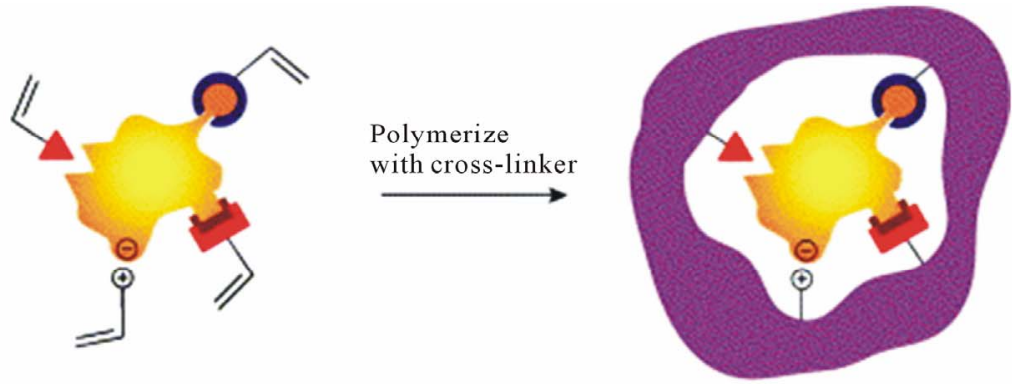
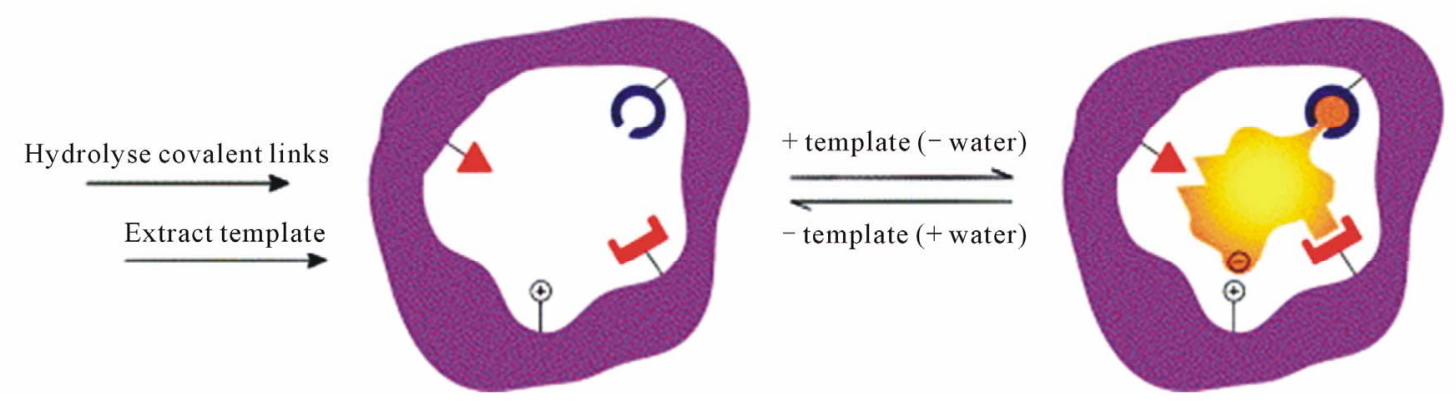

Figure 3. Schematic representation of the molecular imprinting [140].

2,4-D molecules were embedded in the imprinted polypyrrole by hydrogen bond and electrostatic interacttions. Then, the template molecules were removed from the polymer by overoxidized process at $+1.3 \mathrm{~V}$ in $0.2 \mathrm{M}$ $\mathrm{Na}_{2} \mathrm{HPO}_{4}$ solution for $10 \mathrm{~min}$.

\subsection{Analysis of Pesticide Mixtures: The Artificial Neural Networks}

Development of detection systems able to detect several analytes simultaneously represents a promising tool in environmental monitoring and screening. As it has been previously mentioned, numerous organophosphorus and carbamate insecticides can inhibit cholinesterase activity. One limitation of the enzymatic inhibition tests is the difficulty in discriminating between different inhibitors. To solve this problem, a sensor array can be coupled with an Artificial Neural Network (ANN) in order to precisely identify the inhibitors present in the sample. An ANN is a systematic procedure of data processing inspired by the nervous system function in animals. It combines the response of different enzymes to find a pattern that relates inhibitor concentrations with the inhibition percentages observed. Several intelligent biosensors for the analysis of pesticide mixtures have been developed based on the principle of the AChE inhibition and chemometric data analysis using ANNs [146]. Marty's group constructed ANNs to model the combined response of two pesticides (chlorpyrifos oxon and chlorfenvinfos) using sensors incorporating wild-type electric eel AChE and drosophila mutant AChE, associated or not with PTE [147]. These two types of AChEs were selected according to their different sensitivities to OP insecticides. The developed system was applied to the determination of pesticides in real water samples.

\subsection{Nanomaterials}

The emerging synergy between nanotechnology and sensors has been exploited over the past few years [148150]. Intensive research efforts have been performed for the design of efficient nanomaterial-based biosensors that exhibit high sensitivity and stability. The immobilization of nanomaterials onto sensing devices generates novel interfaces that enable the sensitive optical or electrochemical detection of analytes. Recently, some nanomaterials have been used for the design of electrochemical enzyme biosensors. Their high conductivity properties have been reported to enhance the electron transfer between the enzyme redox center and the electrode surface [151]. The electrocatalytic action of nanomaterials decreases the overpotential associated to electroactive compounds, minimizing the interferences present in the sample. In few cases, nanomaterials have been used as labels to amplify the signal measured.

\subsubsection{Nanoparticle-Based Electrochemical Biosensors}

\subsubsection{Enzyme Biosensors}

Various kinds of nanoparticles, such as QDs and AuNPs, have been used for the development of electrochemical enzyme biosensors. An enzyme biosensor was developed for the amperometric detection of trichlorfon using poly (N-vinyl-2-pyrrolidone) (PVP)-capped CdS QDs [152]. The formation of PVP-QD nanostructures on the electrode surface provided a favourable microenvironment and led to a highly sensitive and stable electrochemical 
detection of the enzymatically generated thiocholine product. The detection limit was $4.8 \times 10^{-8} \mathrm{M}$. Another kind of nanoparticles are AuNPs. Their unique property to provide a suitable microenvironment for immobilization of biomolecules retaining their bioactivity is a major advantage for the preparation of biosensors. Moreover, AuNPs facilitate direct electron transfer between immobilized redox proteins and the electrode surface [153]. An electrochemical biosensor based on colloidal AuNP modified sol-gel interface was developed for the detection of monocrotophos, carbaryl and methyl parathion [154]. The assembled AuNPs on a sol-gel derived silicate network provided a conductive pathway to electron transfer and favored the interface enzymatic hydrolysis reaction, increasing the sensitivity of the amperometric response. This biosensor presented good stability, retaining $90 \%$ of its initial current response after a 30-day storage period. Recently, an efficient biosensor for the detection of monocrotophos was developed by combining the unique properties of AuNPS with those of QDs. This new electrochemical system based on CdTe QDs-AuNPs electrode was more sensitive than those based on QDs or AuNPs alone [155].

\subsubsection{Immunosensors}

Recently, an electrochemical immunosensor was developed for rapid screening of diuron, a substituted phenyl urea herbicide [156]. Low cost ablated electrodes fabriccated on polystyrene substrate were modified with Prussian Blue (PB)-AuNP film. The electrodeposition of PBAuNP film enhanced electron transfer in the vicinity of the gold electrode increasing the sensitivity of the system as compared to unmodified gold electrodes. A conductimetric immunosensor for the detection of atrazine was also developed using antibodies labelled with nanoparticles [85]. The authors showed that AuNPs amplify the conductive signal and hence allow the detection of atrazine by means of DC measurements.

\subsubsection{Nanoparticle-Based Optical Biosensors}

Nanoparticles have also been used for the development of efficient optical biosensors [157]. QDs are candidates to replace conventional fluorescent markers. These semiconductor particles are more photostable than an organic fluorophore. Moreover, QDs exhibit higher fluorescence quantum yields than conventional organic fluorophores, allowing higher sensitivity. Recently, an optical biosensor was developed for the detection of monocrotophos using CdTe as fluorescence probe [158]. Using positively charged chitosan, CdTe and acetylcholinesterase were assembled onto a quartz surface by a layer-by-layer technique. In the absence of pesticide, acetylcholine was biocatalytically hydrolyzed inducing the production of choline and acetic acid. The released acid resulted in $\mathrm{pH}$ decrease that was sensed by the immobilized $\mathrm{pH}$ indicator (CdTe). The presence of monocrotophos induced a change of the fluorescence intensity that was related to the pesticide concentration.

Optic properties of AuNPs have been exploited for the development of localized SPR (LSPR) sensor [159,160]. The absorption band of AuNPs results when the incident photon frequency is resonant with the collective oscillation of the conduction electrons and is known as the localized surface plasmon resonance (LSPR). The resonance frequency of the LSPR is highly dependent upon the local environment of the nanoparticle and more specifically upon the binding events that occur to the functionalized NPs. The LSPR was used to develop a biosensor for the detection of paraoxon by immobilizing AChE onto AuNPs layer using a self-assembling technique [157]. In the presence of pesticides, the enzymatic activity was inhibited causing a change of the light attenuation. The detection limit with optimal conditions was $0.2 \mathrm{ppb}$. The biosensor retained $94 \%$ of its original activity after 6 cycles of inhibition with $500 \mathrm{ppb}$ paraoxon followed by reactivation of AChE with $0.5 \mathrm{mM}$ 2pyriding-adoxime methoiodide. In addition, the sensor retained its activity after 2 months storage in dry state at $4^{\circ} \mathrm{C}$.

\subsubsection{Nanotube-Based Electrochemical Biosensors}

Carbon nanotubes (CNTs) consist of cylindrical graphene sheets with nanometer diameters. They present unique mechanical, physical and chemical properties [148]. CNTs include both single-walled and multiwalled structures. Since their discovery, CNTs have been used in nanoelectronics, biomedical engineering, biosensing and bioanalysis.

Electrochemical biosensors, particularly enzyme electrodes, have benefited from the ability of CNT-modified transducers to promote the electron transfer reactions of enzymatically generated species [161]. Recently, CNTs have been used for the development of biosensors based on the inhibition of AChE activity [162-165]. An amperometric biosensor based on layer-by-layer assembly of single walled CNT-poly (diallyldimethylammonium chloride) and AChE was developed for the analysis of carbaryl [164]. The biosensor showed good sensitivity and stability towards the monitoring of pesticides in water. The detection limit was $4.9 \times 10^{-15} \mathrm{M}$.

In some cases, the authors developed efficient biosensors for the detection of pesticides by associating the properties of CNTs with those of nanoparticles $[39,166]$.

\section{Conclusions}

Biosensors are good candidates for the environmental monitoring. They exploit the remarkable specificity of 
recognition elements to design efficient analytical tools that can detect the presence of pesticides in complex samples. The biological elements used for environmental sensing are classically enzymes, antibodies and whole cells. Immunosensors, based on the highly selective and sensitive Ab-Ag reaction, allow the identification of a particular pesticide. Their high specificity can be sometimes a disadvantage. Enzyme-based biosensors allow the detection of broad families of pollutants. Thus, they often offer a general toxicity "index" [167], without providing specific information about a particular pesticide. Genetically engineered AChEs, showing better performance than native enzymes, have been widely exploited in enzyme inhibition-based biosensors for the detection of pesticides. Some genetically engineered microorganisms have also been used to develop microbial biosensors for pesticide detection [150]. In the last decade, aptamers have been used as new molecular recognition elements to develop biosensors [133,134]. However, unique properties of aptamers have not been yet exploited for the development of pesticide analysis. We believe that these recognition elements could be used, in the near future, for the development of efficient aptasensors allowing the detection of pesticides. Although biological receptors have specific molecular affinity and have been widely used in biosensing technology, they are often produced via complex protocols with a high cost and require specific handling conditions because of their poor stability [168]. The high specificity and stability of MIPs render them as promising alternatives to enzymes and Abs [169]. Additional advantages include their compatibility with microfabrication technology and their cost-effectiveness compared to conventional biological receptors.

Nanotechnology is playing an important role in the development of efficient biosensors for the pesticide detection [148-150]. Different types of nanomaterials (e.g. nanoparticles and nanotubes) with different properties have been used. They offer exciting new opportunities to improve the performance of biosensors for the detection of pesticides.

The use of biosensors in environmental field is still limited in comparison to medical applications. Most commercial biosensors are for medical applications, whereas only few are adapted for the environmental monitoring. Thus, there is still a challenge to develop improved and more reliable devices allowing the detection of pesticides.

The use of biosensors in environmental field is still limited in comparison to medical applications. Most commercial biosensors are for medical applications, whereas only few are adapted for the environmental monitoring. Thus, there is still a challenge to develop improved and more reliable devices allowing the detection of pesticides.

\section{REFERENCES}

[1] S. Andreescu and J. L. Marty, "Twenty Years Research in Cholinesterase Biosensors: From Basic Research to Practical Applications,” Biomolecular Engineering, Vol. 23, No. 1, 2006, pp. 1-15. doi:10.1016/j.bioeng.2006.01.001

[2] M. D. Luque de Castro and M. C. Herrera, "Enzyme_ Inhibition-Based Biosensors and Biosensing Systems: Questionable Analytical Devices,” Biosensors and Bioelectronics, Vol. 18, No. 2-3, 2003, pp. 279-294. doi:10.1016/S0956-5663(02)00175-6

[3] N. Jaffrezic-Renault, "New Trends in Biosensors for Organophosphorus Pesticides,” Sensors, Vol. 1, No. 2, 2001, pp. 60-74. doi:10.3390/s10100060

[4] D. Grieshaber, R. MacKenzie, J. Vöros and E. Reimhult, "Electrochemical Biosensors-Sensor Principles and Architectures," Sensors, Vol. 8, No. 3, 2008, pp. 1400-1458. doi:10.3390/s8031400

[5] R. S. Freire, C. A. Pessao, L. D. Mello and L. T. Kubota, "Direct Electron Transfer: An Approach for Electrochemical Biosensors with Higher Selectivity and Sensitivity," Journal of Brazilian Chemical Society, Vol. 14, No. 2, 2003, pp. 230-243. doi:10.1590/S0103-50532003000200008

[6] D. R. Thévenot, K. Toth, R. A. Durst and G. S. Wilson, "Electrochemical Biosensors: Recommended Definitions and Classification,” Pure Applied Chemistry, Vol. 71, No. 12, 1999, pp. 2333-2348. doi:10.1016/S0956-5663(01)00115-4

[7] N. J. Ronkainen, H. B. Halsall and W. R. Heineman, "Electrochemical Biosensors," Chemical Society Reviews, Vol. 39, No. 11, 2010, pp. 1747-1763. doi:10.1039/b714449k

[8] U. Yogeswaran and S.-M. Chen, “A Review on the Electrochemical Sensors and Biosensors Composed of Nanowires as Sensing Material,” Sensors, Vol. 8, No. 1, 2008, pp. 290-313. doi:10.3390/s8010290

[9] S. Liu, L. Yuan, X. Yue, Z. Zheng and Z. Tang, "Recent Advances in Nanosensors for Organophosphates Pesticide Detection," Advanced Powder Technology, Vol. 19, No. 5, 2008, pp. 419-441. doi:10.1016/S0921-8831(08)60910-3

[10] B. Prieto-Simon, M. Campas, S. Andreescu and J. L. Marty, "Trends in Flow-Based Biosensing for Pesticide Assessment,” Sensors, Vol. 6, No. 10, 2006, pp. 11611186. doi:10.3390/s6101161

[11] B. Liu, Y.-H. Yang, Z.-Y. Wu, H. Wang, G.-L. Shen and R.-Q. Yu, “A Potentiometric Acetylcholinesterase Biosensor Based on Plasma-Polymerized Film," Sensors and Actuators B, Vol. 104, No. 2, 2005, pp. 186-190. doi:10.1016/j.snb.2004.04.093

[12] V. G. Andreou and Y. D. Clonis, “A Portable Fiber-Optic Pesticide Biosensor Based On Immobilized Cholinesterase and Sol-Gel Entrapped Bromocresol Purple for In-Field Use," Biosensors and Bioelectronics, Vol. 17, No. 1-2, 2002, pp. 61-69. doi:10.1016/S0956-5663(01)00261-5

[13] F. C. Wong, M. Ahmad, L. Y. Heng and L. B. Peng, “An Optical Biosensor for Dichlovos Using Stacked Sol-Gel Films Containing Acetylcholinesterase and a Lipophilic 
Chromoionophore,” Talanta, Vol. 69, No. 4, 2006, pp. 888-893. doi:10.1016/j.talanta.2005.11.034

[14] H. C. Tsai and R. A. Doong, "Simultaneous Determination of Ph, Urea, Acetylcholine and Heavy Metals Using Array-Based Enzymatic Optical Biosensor,” Biosensors and Bioelectronics, Vol. 20, No. 9, 2005, pp. 1796-1804. doi:10.1016/j.bios.2004.07.008

[15] C. La Rosa, F. Pariente, L. Hernandez and E. Lorenzo, "Amperometric Flow-Through Biosensor for the Determination of Pesticides," Analytica Chimica Acta, Vol. 308, No. 1-3, 1995, pp. 129-136. doi:10.1016/0003-2670(94)00529-U

[16] C. La Rosa, F. Pariente, L. Hernandez and E. Lorenzo, "Determination of Organophosphorus and Carbamic Pesticides with an Acetylcholinesterase Amperometric Biosensor Using 4-Aminophenyl Acetate as Substrate," Analytica Chimica Acta, Vol. 295, No. 3, 1994, pp. 273-282. doi:10.1016/0003-2670(94)80232-7

[17] S. Andreescu, T. Noguer, V. Magearu and J. L. Marty, "Screen-Printed Electrode Based on AChE for the Detection of Pesticides in Presence of Organic Solvents," Talanta, Vol. 57, No. 1, 2002, pp. 169-176. doi:10.1016/S0039-9140(02)00017-6

[18] S. Andreescu, A. Avramescu, C. Bala, V. Magearu and J. L. Marty, "Detection of Organophosphorus Insecticides with Immobilized Acetylcholinesterase-Comparative Study of Two Enzyme Sensors," Analytical and Bioanalytical Chemistry, Vol. 374, No. 1, 2002, pp. 39-45. doi:10.1007/s00216-002-1442-4

[19] S. U padhyay, G. R. Rao, M. K. Sharma, B. K. Bhattacharya, V. K. Rao and R. Vijayaraghavan, "Immobilization of Acetylcholineesterase-Choline Oxidase on a GoldPlatinum Bimetallic Nanoparticles Modified Glassy Carbon Electrode for the Sensitive Detection of Organophosphate Pesticides, Carbamates and Nerves Agents," Biosensors and Bioelectronics, Vol. 25, No. 4, 2009, pp. 832-838. doi:10.1016/j.bios.2009.08.036

[20] L. Campanella, M. Achilli, M. P. Sammartino and Tomassetti, "Butyrylcholine Enzyme Sensor for Determining Organophosphorus Inhibitors,” Journal of Electroanalytical Chemistry, Vol. 321, No. 2, 1991, pp. 237-249. doi:10.1016/0022-0728(91)85599-K

[21] N. G. Karousos, S. Aouabdi, A. S. Way and S. M. Reddy, "Quartz Crystal Microbalance Determination of Organophosphorus and Carbamate Pesticides," Analytica Chimica Acta, Vol. 469, No. 2, 2002, pp. 189-196. doi:10.1016/S0003-2670(02)00668-2

[22] M. Campas, B. Prieto-Simon and J. L. Marty, “A Review of the Use of Genetically Engineered Enzymes in Electrochemical Biosensors," Seminars in Cell and Developmental Biology, Vol. 20, No. 1, 2009, pp. 3-9. doi:10.1016/j.semcdb.2009.01.009

[23] G. Valdes-Ramirez, D. Fournier, M. T. Ramirez-Silva and J. L. Marty, "Sensitive Amperometric Biosensor for Dichlorovos Quantification: Application to Detection of Residues on Apple Skin,” Talanta, Vol. 74, No. 4, 2008, pp. 741-746. doi:10.1016/j.talanta.2007.07.004

[24] F. De Lima, B. Lucca, A. M. J. Barbosa, V. S. Ferreira, S. K. Moccelini, A. C. Franzoi and I. C. Vieira, "Biosensor
Based on Pequi Polyphenol Oxidase Immobilized on Chitosan Crosslinked with Cyanuric Chloride for Thiodicarb Determination," Enzyme and Microbial Technology, Vol. 47, No. 4, 2010, pp. 153-158. doi:10.1016/j.enzmictec.2010.05.006

[25] J. C. Vidal, S. Esteban, J. Gil and J. R. Castillo, “A Comparative Study of Immobilization Methods of a Tyrosinase Enzyme on Electrodes and Their Application to the Detection of Dichlorvos Organophosphorus Insecticide,” Talanta, Vol. 68, No. 3, 2006, pp. 791-799. doi:10.1016/j.talanta.2005.06.038

[26] Y. D. de Albuquerque and L. F. Ferreira, “Amperometric Biosensing of Carbamate and Organophosphate Pesticides Utilizing Screen-Printed Tyrosinase-Modified Electrodes," Analytica Chimica Acta, Vol. 596, No. 2, 2007, pp. 210-221. doi:10.1016/j.aca.2007.06.013

[27] G.-Y. Kim, M.-S. Kang and S.-H. Moon, "Sub-strateBound Tyrosinase Electrode Using Gold Nanoparticles Anchored to Pyrroloquinoline Quinone for a Pesticide Biosensor," Sensors and Actuators B, Vol. 133, No. 1, 2008, pp. 1-4. doi:10.1016/j.snb.2008.01.055

[28] G. Y. Kim, J. Shim, M. S. Kang and S. H. Moon, "Optimized Coverage of Gold Nanoparticles at Tyrosinase Electrode for Measurement of a Pesticide in Various Water Samples,” Journal of Hazardous Materials, Vol. 156, No. 1-3, 2008, pp. 141-147. doi:10.1016/j.jhazmat.2007.12.007

[29] L. Campanella, D. Lelo, E. Martini and M. Tomassetti, "Organophosphorus and Carbamate Pesticide Analysis Using an Inhibition Tyrosinase Organic Phase Enzyme Sensor; Comparison by Butyrylcholinesterase + Choline Oxidase Opee and Application to Natural Waters," Analytica Chimica Acta, Vol. 587, No. 1, 2007, pp. 22-32. doi:10.1016/j.aca.2007.01.023

[30] M. S. Ayyagari, S. Kamtekar, R. Pande, K. A. Marx, J. Kumar, S. K. Tripathy and D. L. Kaplan, "Biosensors for Pesticide Detection Based on Alkaline Phosphatase-Catalyzed Chemiluminescence," Materials Science and Engineering: C, Vol. 2, No. 4, 1995, pp. 191-196. doi:10.1016/0928-4931(95)00077-1

[31] F. Garcia Sanchez, A. Navas Diaz, M. C. Ramos Peinado and C. Belledone, "Free and Sol-Gel Immobilized Alkaline Phosphatase-Based Biosensor for the Determination of Pesticides and Inorganic Compounds," Analytica Chimica Acta, Vol. 484, No. 1, 2003, pp. 45-51. doi:10.1016/S0003-2670(03)00310-6

[32] F. Mazzei, F. Botrè, S. Montilla, R. Pilloton, E. Podesta and C. Botrè, "Alkaline Phosphatase Inhibition Based Electrochemical Sensors for the Detection of Pesticides," Journal of Electroanalytical Chemistry, Vol. 574, No. 1, 2004, pp. 95-100. doi:10.1016/j.jelechem.2004.08.004

[33] L. K. Shyuan, L. Y. Heng, M. Ahmad, S. A. Aziz and Z. Ishak, "Evaluation of Pesticide and Heavy Mtal Toxicity Using Immobilised Enzyme Alkaline Phosphatase with an Electrochemical Biosensor," Asian Journal of Biochemistry, Vol. 3, No. 6, 2008, pp. 359-365. doi:10.3923/ajb.2008.359.365

[34] S. K. Moccelini, I. C. Vieira, F. De Lima, B. Lucca, A. M. J. Barbosa and V. S. Ferreira, "Determination of Thiodi- 
carb Using a Biosensor Based on Alfalfa Sprout Peroxidase Immobilized in Self-Assembled Monolayers," Talanta, Vol. 82, No. 1, 2010, pp. 164-170.

doi:10.1016/j.talanta.2010.04.015

[35] S. Yang, Y. Li, X. Jiang, Z. Chen and X. Lin, "Horseradish Peroxidase Biosensor Based on Layer-by-Layer Technique for the Determination of Phenolic Compounds," Sensors and Actuators B, Vol. 114, No. 2, 2006, pp. 774-780. doi:10.1016/j.snb.2005.07.035

[36] S. Yang, Z. Chen, X. Jin and X. Lin, "HRP Biosensor Based on Sugar-Lectin Biospecific Interactions for the Determination of Phenolic Compounds," Electrochimica Acta, Vol. 52, No. 1, 2006, pp. 200-205.

doi:10.1016/j.electacta.2006.04.059

[37] F. Mazzei, F. Botrè and C. Botrè, “Acid Phosphatase/Glucose Oxidase-Based Biosensors for the Determination of Pesticides," Analytica Chimica Acta, Vol. 336, No. 1, 1996, pp. 67-75. doi:10.1016/S0003-2670(96)00378-9

[38] A. Mulchandani, W. Chen, P. Mulchandani, J. Wang and K. R. Rogers, "Biosensors for Direct Determination of Organophosphate Pesticides," Biosensors and Bioelectronics, Vol. 16, No. 4, 2001, pp. 225-230. doi:10.1016/S0956-5663(01)00126-9

[39] D. Du, W. Chen, W. Zhang, D. Liu, H. Li and Y. Lin, "Covalent Coupling of Organophosphorus Hydrolase Loaded Quantum Dots to Carbon Nanotube. Au Nanocomposite for Enhanced Detection of Methyl Parathion," Biosensors and Bioelectronics, Vol. 25, No. 6, 2010, pp. 1370-1375. doi:10.1016/j.bios.2009.10.032

[40] J. H. Lee, J. Y. Park, K. Min, H. J. Cha, S. S. Choi and Y. J. Yoo, "A Novel Organophosphorus Hydrolase-Based Biosensor Using Mesoporous Carbons and Carbon Black for the Detection of Organophosphate Nerve Agents," Biosensors and Bioelectronics, Vol. 25, No. 7, 2010, pp. 1566-1570. doi:10.1016/j.bios.2009.10.013

[41] V. A. Pedrosa, S. Paliwal, S. Balasubramanian, D. Nepal, V. Davis, J. Wild, E. Ramanculov and A. Simonian, "Enhanced Stability of Enzyme Organophosphate Hydrolase Interfaced on the Carbon Nanotubes," Colloids and Surfaces B Biointerfaces, Vol. 77, No. 1, 2010, pp. 69-74. doi:10.1016/j.colsurfb.2010.01.009

[42] V. G. Andreou and Y. D. Clonis, "Novel Fiber-Optic Biosensor Based on Immobilized Glutathione $S$-Transferase and Sol-Gel Entrapped Bromcresol Green for the Determination of Atrazine," Analytica Chimica Acta, Vol. 460, No. 2, 2002, pp. 151-161. doi:10.1016/S0003-2670(02)00250-7

[43] Y. Lei, W. Chen and A. Mulchandani, "Microbial Biosensors," Analytica Chimica Acta, Vol. 568, No. 1-2, 2006, pp. 200-210. doi:10.1016/j.aca.2005.11.065

[44] S. F. D’Souza, "Microbial Biosensors," Biosensors and Bioelectronics, Vol. 16, 2001, pp. 337-353. doi:10.1016/S0956-5663(01)00125-7

[45] J. Liu and B. Mattiasson, "Microbial BOD Sensors for Wastewater Analysis," Water Research, Vol. 36, No. 15, 2002, pp. 3786-3802. doi:10.1016/S0043-1354(02)00101-X

[46] C. Chan, M. Lehmann, K. Chan, P. Chan, C. Chan, B. Gruendig, G. Kunze and R. Renneberg, "Designing an
Amperometric Thick-Film Microbial BOD Sensor,” Biosensors and Bioelectronics, Vol. 15, No. 7-8, 2000, pp. 343-353. doi:10.1016/S0043-1354(02)00101-X

[47] K. Riedel, R. Renneberg, M. Kühn and F. Scheller, “A Fast Estimation of Biochemical Oxygen Demand Using Microbial Sensors," Applied Microbiology and Biotechnology, Vol. 28, No. 3, 1988, pp. 316-318. doi:10.1007/BF00250463

[48] M. N. Kim and H. S. Kwon, "Biochemical Oxygen Demand Sensor Using Serratia marcescens LSY 4,” Biosensors and Bioelectronics, Vol. 14, No. 1, 1999, pp. 1-7. doi:10.1016/S0956-5663(98)00107-9

[49] M. Hikuma, H. Suzuki, T. Yasuda, I. Karube and S. Suzuki, "Amperometric Estimation of BOD by Using Living Immobilized Yeast," European Journal of Applied Microbiology and Biotechnology, Vol. 8, No. 4, 1979, pp. 289-297. doi:10.1007/BF00508793

[50] J. Jia, M. Tang, X. Chen, L. Qi and S. Dong, “Co-Immobilized Microbial Biosensor for Bod Estimation Based on Sol-Gel Derived Composite Material," Biosensors and Bioelectronics, Vol. 18, No. 8, 2003, pp. 1023-1029. doi:10.1016/S0956-5663(02)00225-7

[51] J. Liu, G. Olsson and B. Mattiasson, "Short-Term BOD $\left(\mathrm{BOD}_{\mathrm{st}}\right)$ as a Parameter for On-Line Monitoring of Biological Treatment Process Part I. A Novel Design of BOD Biosensor for Easy Renewal of Bio-Receptor," Biosensors and Bioelectronics, Vol. 20, No. 3, 2004, pp. 562570. doi:10.1016/j.bios.2004.03.008

[52] L. Su, W. Jia, C. Hou and Y. Lei, "Microbial Biosensors: A Review," Biosensors and Bioelectronics, Vol. 26, No. 5, 2011, pp. 1788-1799. doi:10.1016/j.bios.2010.09.005

[53] P. Mulchandani, C. M. Hangarter, Y. Lei, W. Chen and A. Mulchandani, “Amperometric Microbial Biosensor for pNitrophenol Using Moraxella sp.-Modified Carbon Paste Electrode," Biosensors and Bioelectronics, Vol. 21, No. 12, 2005, pp. 523-527. doi:10.1016/j.bios.2004.11.011

[54] Y. Lei, P. Mulchandani, W. Chen, J. Wang and A. Mulchandani, "Whole Cell-Enzyme Hybrid Amperometric Biosensor for Direct Determination of Organophosphorous Nerve Agents with p-Nitrophenyl Substituent,” Biotechnology and Bioengineering, Vol. 85, No. 7, 2004, pp. 706-712. doi:10.1002/bit.20022

[55] Y. Lei, P. Mulchandani, W. Chen and A. Mulchandani, "Direct Determination of p-Nitrophenyl Substituent Organophosphorus Nerve Agents Using a Recombinant Pseudomonas putida JS444-Modified Clark Oxygen Electrode," Journal of Agricultural and Food Chemistry, Vol. 53, 2005, pp. 524-527. doi:10.1021/jf048943t

[56] Y. Lei, P. Mulchandani, W. Chen and A. Mulchandani, "Biosensor for Direct Determination of Fenitrothion and EPN Using Recombinant Pseudomonas putida JS444 with Surface Expressed Organophosphorus Hydrolase. 1. Modified Clark Oxygen Electrode,” Sensors, Vol. 6, No. 4, 2006, pp. 466-472. doi:10.3390/s6040466

[57] P. Mulchandani, W. Chen and A. Mulchandani, "Microbial Biosensor for Direct Determination of NitrophenylSubstituted Organophosphate Nerve Agents Using Genetically Engineered Moraxella sp.," Analytica Chimica Acta, Vol. 568, No. 1-2, 2006, pp. 217-221. 
doi:10.1016/j.aca.2005.11.063

[58] E. I. Rainina, E. N. Efremenco, S. D. Varfolomeyev, A. L. Simonian and J. R. Wild, "The Development Of A New Biosensor Based on Recombinant E. coli for the Direct Detection of Organophosphorus Neurotoxins," Biosensors and Bioelectronics, Vol. 11, No. 10, 1996, pp. 9911000. doi:10.1016/0956-5663(96)87658-5

[59] F. Lagarde and N. Jaffrezic-Renault, "Cell-Based Electrochemical Biosensors for Water Quality Assessment," Analytical and Bioanalytical Chemistry, Vol. 400, No. 4, 2011, pp. 947-964. doi:10.1007/s00216-011-4816-7

[60] J. Kumar, S. K. Jha and S. F. D’Souza, “Optical Microbial Biosensor for Detection of Methyl Parathion Pesticide Using Flavobacterium sp. Whole Cells Adsorbed on Glass Fiber Filters as Disposable Biocomponent,” Biosensors and Bioelectronics, Vol. 21, No. 11, 2006, pp. 2100-2105. doi:10.1016/j.bios.2005.10.012

[61] M. Campas, R. Carpentier and R. Rouillon, "Plant-Tissue-and Photosynthesis-Based Biosensors," Biotechology Advances, Vol. 26, No. 4, 2008, pp. 370-378. doi:10.1016/j.biotechadv.2008.04.001

[62] C. Chouteau, S. V. Dzyadevych, J.-M. Chovelon and C. Durrieu, "Development of Novel Conductometric Biosensors Based on Immobilised Whole Cell Chlorella vulgaris Microalgae,” Biosensors and Bioelectronics, Vol. 19, No. 9, 2004, pp. 1089-1096. doi:10.1016/j.bios.2003.10.012

[63] C. Chouteau, S. V. Dzyadevych, C. Durrieu and J.-M. Chovelon, "A Bi-Enzymatic Whole Cell Conductometric Biosensor for Heavy Metal Ions and Pesticides Detection in Water Samples,” Biosensors and Bioelectronics, Vol. 21, No. 2, 2005, pp. 273-281. doi:10.1016/j.bios.2004.09.032

[64] H. Guedri and C. Durrieu, "A Self-Assembled Monolayers Based Conductimetric Algal Whole Cell Biosensor for Water Monitoring," Microchimica Acta, Vol. 163, No. 3-4, 2008, pp. 179-184. doi:10.1007/s00604-008-0017-2

[65] R. Rouillon, S. A. Piletsky, E. V. Piletska, P. Euzet and R. Carpentier, "Comparison of the Immobilization Techniques for Photosystem II,” In: M. T. Giardi and E. V. Piletska, Eds., Biotechnological Applications of Photosynthesis Proteins: Biochips, Biosensors and Biodevices, Landes Bioscience, Georgetown, 2006, pp. 73-83.

[66] M. T. Giardi and E. Pace, "Photosystem II-Based Biosensors for the Detection of Photosynthetic Herbicides," In: M. Giardi and E. V. Piletska, Eds., Biotechnological Applications of Photosynthetic Proteins; Biochips, Biosensors and Biodevices, Landes Bioscience, Georgetown, 2006, pp. 147-154. doi:10.1007/978-0-387-36672-2_13

[67] R. Rouillon, J.-J. Mestres and J. L. Marty, “Entrapment of Chloroplasts and Thylakoids in Polyvinylalcohol-SbQ. Optimization of Membrane Preparation and Storage Conditions," Analytica Chimica Acta, Vol. 311, No. 3, 1995, pp. 437-442. doi:10.1016/0003-2670(95)00031-T

[68] M. Koblizek, J. Masojidek, J. Komenda, T. Kucera, R. Pilloton, A. K. Mattoo and M. T. Giardi, “A Sensitive Photosystem II-Based Biosensor for Detection of a Class of Herbicides,” Biotechnology Bioengeering, Vol. 60, No. 6, 1998, pp. 664-669. doi:10.1002/(SICI)1097-0290
[69] I. Shitanda, K. Takada, T. Sakai and T. Tatsuma, “Compact Amperometric Algal Biosensors for the Evaluation of Water Toxicity," Analytica Chimica Acta, Vol. 530, No. 2, 2005, pp. 191-197. doi:10.1016/j.aca.2004.09.073

[70] I. Shitanda, S. Takamatsu, K. Watanabe and M. Itagaki, "Amperometric Screen-Printed Algal Biosensor with Flow Injection Analysis System for Detection of Environmental Toxic Compounds," Electrochimica Acta, Vol. 54, No. 21, 2009, pp. 4933-4936. doi:10.1016/j.electacta.2009.04.005

[71] H. Nguyen-Ngoc and C. Tran-Minh, "Fluorescent Biosensor Using Whole Cells in an Inorganic Translucent Matrix," Analytica Chimica Acta, Vol. 583, No. 1, 2007, pp. 161-165. doi:10.1016/j.aca.2006.10.005

[72] C. Védrine, J. C. Leclerc, C. Durrieu and C. Tran-Minh, "Optical Whole-Cell Biosensor Using Chlorella Vulgaris Designed for Monitoring Herbicides," Biosensors and Bioelectronics, Vol. 18, No. 4, 2003, pp. 457-463. doi:10.1016/S0956-5663(02)00157-4

[73] A. Ventrella, L. Catucci and A. Agostiano, "Herbicides Affect Fluorescence and Electron Transfer Activity of Spinach Chloroplasts, Thylakoid Membranes and Isolated Photosystem II," Bioelectrochemistry, Vol. 79, No. 1, 2010, pp. 43-49. doi:10.1016/j.bioelechem.2009.10.008

[74] E. Pena-Vazquez, E. Maneiro, C. Perez-Conde, M. C. Moreno-Bondi and E. Costas, "Microalgae Fiber Optic Biosensors for Herbicide Monitoring Using Sol-Gel Technology," Biosensors and Bioelectronics, Vol. 24, No.12, 2009, pp. 3538-3543. doi:10.1016/j.bios.2009.05.013

[75] X. Jiang, D. Li, X. Xu, Y. Ying, Y. Li, Z. Ye and J. Wang, "Immunosensors for Detection of Pesticides Residues," Biosensors and Bioelectronics, Vol. 23, No. 11, 2008, pp. 1577-1587. doi:10.1016/j.bios.2008.01.035

[76] C.R. Suri, R. Boro, Y. Nangia, S. Gandhi, P. Sharma, N. Wangoo, K. Rajesh and G. S. Shekhawat, "Immunoanalytical Techniques for Analyzing Pesticides in the Environment," Trends in Analytical Chemistry, Vol. 28, No. 1, 2009, pp. 29-39. doi:10.1016/j.trac.2008.09.017

[77] E. Mallat, D. Barcelo, C. Barzen, G. Gauglitz and R. Abuknesha, "Immunosensors for Pesticide Determination in Natural Waters," Trends in Analytical Chemistry, Vol. 20, No. 3, 2001, pp. 124-132. doi:10.1016/S0165-9936(00)00082-0

[78] F. F. Bier, E. Ehrentreich-Förster, R. Dölling, A. V. Eremenko and F. W. Scheller, "A Redox Label Immunosensor on Basis of a Bi-Enzyme Electrode,” Analytica Chimica Acta, Vol. 344, No. 1-2, 1997, pp. 119-124. doi:10.1016/S0003-2670(97)00050-0

[79] T. Kalab and P. Skadal, “A Disposable Amperometric Immunosensor for 2,4-Dichlorophenoxyacetic Acid,” Analytica Chimica Acta, Vol. 304, No. 3, 1995, pp. 361-368. doi:10.1016/0003-2670(94)00641-X

[80] P. Skadal and T. Kalab, “A Multichannel Immunochemical Sensor for the Determination of 2,4-Dichlorophenoxyacetic Acid,” Analytica Chimica Acta, Vol. 316, No. 1, 1995, pp. 73-78. doi:10.1016/0003-2670(95)00342-W

[81] S. Kröger, S. J. Setford and A. P. F. Turner, "Immunosensor for 2,4-Dichlorophenoxyacetic Acid in Aqueous/Organic 
Solvents Soil Extracts,” Analytical Chemistry, Vol. 70, No. 23, 1998, pp. 5047-5053. doi:10.1021/ac9805100

[82] K. Grennan, G. Strachan, A. J. Porter, A. Killard and M. R. Smyth, "Atrazine Analysis Using an Amperometric Immunosensor Based on Single-Chain Antibody Fragments and Regeneration-Free Multi-Calibrant Measurement," Analytica Chimica Acta, Vol. 500, No. 1-2, 2003, pp. 287-298. doi:10.1016/S0003-2670(03)00942-5

[83] E. Valera, D. Muniz and A. Rodriguez, "Fabrication of Flexible Interdigitated $\mu$-Electrodes (FID $\mu$ Es) for the Development of a Conductimetric Immunosensor for Atrazine Detection Based on Antibodies Labelled with Gold Nanoparticles," Microelectronic Engineering, Vol. 87, No. 2, 2010, pp. 167-173. doi:10.1016/j.mee.2009.07.001

[84] E. Valera, J. Ramon-Azcon, A. Barranco, B. Alfaro, F. Sanchez-Baeza, M. P. Marco and A. Rodriguez, "Determination of Atrazine Residues in Red Wine Samples. A Conductimetric Solution," Food Chemistry, Vol. 122, No. 3, 2010, pp. 888-894. doi:10.1016/j.foodchem.2010.03.030

[85] E. Valera, J. Ramon-Azcon, F. J. Sanchez, M. P. Marco and A. Rodriguez, "Conductimetric Immunosensor for Atrazine Detection Based on Antibodies Labelled with Gold Nanoparticles,” Sensors and Actuators B, Vol. 134, No. 1, 2008, pp. 95-103. doi:10.1016/j.snb.2008.04.023

[86] Y. V. Plekhanova, A. N. Reshetilov, E. V. Yazynina, A. V. Zherdev and B. B. Dzantiev, "A New Assay Format for Electrochemical Immunosensors: Polyelectrolyte- Based Separation on Membrane Carriers Combined with Detection of Peroxidase Activity by $\mathrm{pH}$-Sensitive Field-Effect Transistor," Biosensors and Bioelectronics, Vol. 19, No. 2, 2003, pp. 109-114. doi:10.1016/S0956-5663(03)00176-3

[87] M. F. Yulaev, R. A. Sidtikov, N. M. Dmitrieva, E. V. Yazynima, A. V. Zherdev and B. B. Dzantiev, "Development of a Potentiometric Immunosensor for Herbicide Simazine and Its Application for Food Testing,” Sensors and Actuators B, Vol. 75, No. 1-2, 2001, pp. 129-135. doi:10.1016/S0925-4005(01)00551-2

[88] L. Mosiello, C. Laconi, M. Del Gallo, C. Ercole and A. Lepidi, "Development of a Monoclonal Antibody Based Potentiometric Biosensor for Terbuthylazine Detection,” Sensors and Actuators B, Vol. 95, No. 1-3, 2003, pp. 315320. doi:10.1016/S0925-4005(03)00431-3

[89] H. B. Fredj, S. Helali, Z. Sassi, N. Jaffrezic-Renault and A. Abdelghani, "Polyaniline Based Immunosensor for Atrazine Sensing,” Sensor Letters, Vol. 7, No. 5, 2009, pp. 661- 666. doi:10.1166/sl.2009.1126

[90] A. Rodriguez, E. Valera, J. Ramon-Azcon, F. J. Sanchez, M. P. Marco and L. M. Castaner, "Single Frequency Impedimetric Immunosensor for Atrazine Detection," Sensors and Actuators B, Vol. 129, No. 2, 2008, pp. 921-928. doi:10.1016/j.snb.2007.10.003

[91] E. Valera, J. Ramon-Azcon, A. Rodriguez, L. M. Castaner, F. J. Sanchez and M. P. Marco, "Impedimetric immunosensor for Atrazine Detection Using Interdigitated $\mu$-Electrode (ID $\mu$ E's)," Sensors and Actuators B, Vol. 125, No. 2, 2007, pp. 526-537. doi:10.1016/j.snb.2007.02.048
[92] J. Ramon-Azcon, E. Valera, A. Rodriguez, A. Barranco, B. Alfaro, F. Sanchez-Baeza and M. P. Marco, “An Impedimetric Immunosensor Based on Interdigitated Microelectrodes $(\mathrm{ID} \mu \mathrm{E})$ for the Determination of Atrazine Residues in Food Samples," Biosensors and Bioelectronics, Vol. 23, No. 9, 2008, pp. 1367-1373. doi:10.1016/j.bios.2007.12.010

[93] R. E. Ionescu, C. Gondran, L. Bouffier, N. Jaffrezic-Renault, C. Martelet and S. Cosnier, "Label-Free Impedimetric Immunosensor for Sensitive Detection of Atrazine," Electrochimica Acta, Vol. 55, No. 21, 2010, pp. 6228-6232. doi:10.1016/j.electacta.2009.11.029

[94] C. Esseghaier, S. Helali, H. Fredj, A. Tlili and A. Abdelghani, "Polypyrrole-Neutravidin Layer for Impedimetric Biosensor," Sensors and Actuators B, Vol. 131, No. 2, 2008, pp. 584-589. doi:10.1016/j.snb.2007.12.043

[95] S. Helali, C. Martelet, A. Abdelghani, M. A. Maaref and N. Jaffrezic-Renault, “A Disposable Immunomagnetic Electrochemical Sensor Based on Functionalised Magnetic Beads on Gold Surface for the Detection of Atrazine," Electrochimica Acta, Vol. 51, No. 24, 2006, pp. 51825186. doi:10.1016/j.electacta.2006.03.086

[96] B. Corry, J. Uilk and C. Crawley, "Probing Direct Binding Affinity in Electrochemical Antibody-Based Sensors," Analytica Chimica Acta, Vol. 496, No. 1-2, 2003, pp. 103-116. doi:10.1016/j.aca.2003.01.001

[97] S. Hleli, C. Martelet, A. Abdelghani, N. Burais and N. Jaffrezic-Renault, "Atrazine Analysis Using an Impedimetric Immunosensor Based on Mixed Biotinylated SelfAssembled Monolayer," Sensors and Actuators B, Vol. 113, No. 2, 2006, pp. 711-717. doi:10.1016/j.snb.2005.07.023

[98] J. Homola, S. S. Yee and G. Gauglitz, "Surface Plasmon Resonance Sensors: Review," Sensors and Actuators B, Vol. 54, No. 1-2, 1999, pp. 3-15. doi:10.1016/S0925-4005(98)00321-9

[99] M. Farre, E. Martinez, J. Ramon, A. Navarro, J. Radjenovic, E. Mauriz, L. Lechuga, M. P. Marco and D. Barcelo, "Part per Trillion Determination of Atrazine in Natural Water Samples by a Surface Plasmon Resonance Immunosensor," Analytical and Bioanalytical Chemistry, Vol. 388, No. 1, 2007, pp. 207-214. doi:10.1007/s00216-007-1214-2

[100] E. Mauriz, A. Calle, J. J. Manclus, A. Montoya and L. M. Lechuga, "Multi-Analyte SPR Immunoassays for Environmental Biosensing of Pesticides," Analytical and Bioanalytical Chemistry, Vol. 387, No. 4, 2006, pp. 14491458. doi:10.1007/s00216-006-0800-z

[101] E. Mauriz, A. Calle, A. Abad, A. Montoya, A. Hildebrandt, D. Barcelo and L. M. Lechuga, "Determination of Car0 baryl in Natural Water Samples by a Surface Plasmon Resonance Flow-Through Immunosensor," Biosensors and Bioelectronics, Vol. 21, No. 11, 2006, pp. 2129-2136. doi:10.1016/j.bios.2005.10.013

[102] E. Mauriz, A. Calle, J. J. Manclus, A. Montoya, A. M. Escuela, J. R. Sendra and L. M. Lechuga, "Single and Multi-Analyte Surface Plasmon Resonance Assays for Simultaneous Detection Of Cholinesterase Inhibiting Pesticides," Sensors and Actuators B, Vol. 118, No. 1-2, 2006, pp. 399-407. doi:10.1016/j.snb.2006.04.085 
[103] E. Mauriz, A. Calle, L. M. Lechuga, J. Quintana, A. Montoya and J. J. Manclus, "Real-Time Detection of Chlorpyrifos at Part Per Trillion Levels in Ground, Surface and Drinking Water Samples by a Portable Surface Plasmon Resonance Immunosensor," Analytica Chimica Acta, Vol. 561, No. 1-2, 2006, pp. 40-47. doi:10.1016/j.aca.2005.12.069

[104] E. Mauriz, A. Calle, A. Montoya and L. M. Lechuga, "Determination of Environmental Organic Pollutants with a Portable Optical Immunosensor,” Talanta, Vol. 69, No. 2, 2006, pp. 359-364. doi:10.1016/j.talanta.2005.09.049

[105] S. J. Kim, K. V. Gobi, H. Tanaka, Y. Shoyama and N. Miura, “A Simple and Versatile Self-Assembled Monolayer Based Surface Plasmon Resonance Immunosensor for Highly Sensitive Detection of 2,4-D from Natural Water Resources,” Sensors and Actuators B, Vol. 130, No. 1, 2008, pp. 281-289. doi:10.1016/j.snb.2007.08.023

[106] K. V. Gobi, S. J. Kim, H. Tanaka, Y. Shoyama and N. Miura, "Novel Surface Plasmon Resonance (SPR) Immunosensor Based on Monomolecular Layer of Physically-Adsorbed Ovalbumin Conjugate for Detection of 2,4-Dichlorophenoxyacetic Acid and Atomic Force Microscopy Study," Sensors and Actuators B, Vol. 123, No. 1, 2007, pp. 583-593. doi:10.1016/j.snb.2006.09.056

[107] K. V. Gobi, H. Tanaka, Y. Shoyama and N. Miura, "Highly Sensitive Regenerable Immunosensor for LabelFree Detection of 2,4-Dichlorophenoxyacetic Acid at ppb Levels by Using Surface Plasmon Resonance Imaging," Sensors and Actuators B, Vol. 111-112, 2005, pp. 562571. doi:10.1016/j.snb.2005.03.118

[108] S. J. Kim, K. V. Gobi, H. Iwasaka, H. Tanaka and N. Miura, "Novel Miniature SPR Immunosensor Equipped with All-in-One Multichannel Sensor Chip for Detecting Low-Molecular-Weight Analytes," Biosensors and Bioelectronics, Vol. 23, No. 5, 2007, pp. 701-707. doi:10.1016/j.bios.2007.08.010

[109] C. M. Cummins, M. E. Koivunen, A. Stephanian, S. J. Gee, B. D. Hammock and I. M. Kennedy, "Application of Europium(III) Chelate-Dyed Nanoparticle Labels in a Competitive Atrazine Fluoroimmunoassay on an ITO Waveguide," Biosensors and Bioelectronics, Vol. 21, No. 7, 2003, pp. 1077-1085.

[110] A. Klotz, A. Brecht, C. Barzen, G. Gauglitz, R. D. Harris, G. R. Quigley, J. S. Wilkinson and R. Abuknesha, "Immunofluorescence Sensor for Water Analysis,” Sensors and Actuators B, Vol. 51, No. 1-3, 1998, pp. 181-187. doi:10.1016/S0925-4005(98)00187-7

[111] C. Barzen, A. Brecht and G. Gauglitz, “Optical MultipleAnalyte Immunosensor for Water Pollution Control," Biosensors and Bioelectronics, Vol. 17, No. 4, 2002, pp. 289-295. doi:10.1016/S0956-5663(01)00297-4,

[112] F. Long, H. C. Shi, M. He and A. N. Zhu, "Sensitive and Rapid Detection of 2,4-Dicholorophenoxyacetic Acid in Water Samples by Using Evanescent Wave All-Fiber Immunosensor," Biosensors and Bioelectronics, Vol. 23, No. 9, 2008, pp. 1361-1366. doi:10.1016/j.bios.2007.12.004

[113] F. Long, M. He, H. C. Shi and A. N. Zhu, "Development of Evanescent Wave All-Fiber Immunosensor for Environmental Water Analysis," Biosensors and Bioelectron- ics, Vol. 23, No. 7, 2008, pp. 952-958. doi:10.1016/j.bios.2007.09.013

[114] S. Rodriguez-Mozaz, M. L. de Alda and D. Barcelo, "Analysis of Bisphenol A in Natural Waters by Means of an Optical Immunosensor,” Water Research, Vol. 39, No. 20, 2005, pp. 5071-5079.

doi:10.1016/j.watres.2005.09.023

[115] J. Tschmelak, N. Kappel and G. Gauglitz, “TIRF-Based Biosensor for Sensitive Detection of Progesterone in Milk Based on Ultra-Sensitive Progesterone Detection in Water," Analytical and Bioanalytical Chemistry, Vol. 382, No. 8, 2005, pp. 1895-1903. doi:10.1007/s00216-005-3261-X

[116] J. Tschmelak, G. Proll, J. Riedt, J. Kaiser, P. Kraemmer, L. Barzaga, J. S. Wilkinson, P. Hua, J. P. Hole, R. Nudd, M. Jackson, R. Abuknesha, D. Barcelo, S. RodriguezMozaz, M. J. de Alda, F. Sacher, J. Stien, J. Slobodnik, P. Oswald, H. Kozmenko, E. Korenkova, L. Tothova, Z. Krascsenits and G. Gauglitz, "Automated Water Analyser Computer Supported System (AWACSS) Part I: Project Objectives, Basic Technology, Immunoassay Development, Software Design and Networking," Biosensors and Bioelectronics, Vol. 20, No. 8, 2005, pp. 1499-1508. doi:10.1016/j.bios.2004.07.032

[117] S. Boujday, S. Nasri, M. Salmain and C.-M. Pradier, "Surface IR Immunosensors for Label-Free Detection of Benzo[a]pyrene,” Biosensors and Bioelectronics, Vol. 26, No. 4, 2010, pp. 1750-1754.

[118] S. Boujday, C. Gu, M. Girardot, M. Salmain and C. M. Pradier, "Surface IR Applied to Rapid and Direct Immunosensing of Environmental Pollutants,” Talanta, Vol. 78, No. 1, 2009, pp. 165-170. doi:10.1016/j.talanta.2008.10.064

[119] M. Salmain, N. Fischer-Durand and C. M. Pradier, "Infrared optical immunosensors: Application to the MeasUrement of the Herbicide Atrazine," Analytical Biochemistry, Vol. 373, No. 1, 2008, pp. 61-70. doi:10.1016/j.ab.2007.10.031

[120] S. Kurosawa, J.-W. Park, H. Aiwaza, S.-I. Wakida, H. Tao and K. Ishihara, "Quartz Crystal Microbalance Immunosensor for Environmental Monitoring,” Biosensors and Bioelectronics, Vol. 22, No. 4, 2006, pp. 473-481. doi:10.1016/j.bios.2006.06.030

[121] C. March, J. J. Manclus, Y. Jimenez, A. Arnau and A. Montoya, "A Piezoelectric Immunosensor for the Determination of Pesticide Residues and Metabolites in Fruit Juices,” Talanta, Vol. 78, No. 3, 2009, pp. 827-833. doi:10.1016/j.talanta.2008.12.058

[122] A. Sassolas, B. D. Leca-Bouvier and L. J. Blum, "DNA Biosensors and Microarrays," Chemical Reviews, Vol. 108, No. 1, 2008, pp. 109-139. doi:10.1021/cr0684467

[123] J. Kaur, K. V. Singh, A. H. Schmid, G. C. Varshney, C. R. Suri and M. Raje, "Atomic Force Spectroscopy-Based Study of Antibody Pesticide Interactions for Characterization of Immunosensor Surface," Biosensors and Bioelectronics, Vol. 20, No. 2, 2004, pp. 284-293. doi:10.1016/j.bios.2004.01.012

[124] C. R. Suri, J. Kaur, S. Gandhi and G. S. Shekhawat, "Label-free Ultra-Sensitive Detection of Atrazine Based on 
Nanomechanics,” Nanotechnology, Vol. 19, No. 23, 2008, p. 235502. doi:10.1088/0957-4484/19/23/235502

[125] M. Alvarez, A. Calle, J. Tamayo, L. Lechuga, A. Abad and A. Montoya, "Development of Nanomechanical Biosensors for Detection of the Pesticide DDT," Biosensors and Bioelectronics, Vol. 18, No. 5-6, 2003, pp. 649-653. doi:10.1016/S0956-5663(03)00035-6

[126] M. Bache, R. Taboryski, S. Schmid, J. Aamand and M. H. Jakobsen, "Investigations on Antibody Binding to a Microcantilever Coated with a BAM Pesticide Residue," Nanoscale Research Letters, Vol. 6, 2011, p. 386.

[127] A. M. Nowicka, A. Kowalczyk, Z. Stojek and M. Hepel, "Nanogravimetric and Voltammetric DNA-Hybridization Biosensors for Studies of DNA Damage by Common Toxicants and Pollutants,” Biophysical Chemistry, Vol. 146, No. 1, 2010, pp. 42-53. doi:10.1016/j.bpc.2009.10.003

[128] A. D. Ellington and J. W. Szostak, "In Vitro Selection of RNA Molecules that Bind Specific Ligands,” Nature, Vol. 346, No. 6287, 1990, pp. 818-822. doi:10.1038/346818a0

[129] C. L. A. Hamula, J. W. Guthrie, H. Zhang, X.-F. Li and X. C. Le, "Selection and Analytical Applications of Aptamers," Trends in Analytical Chemistry, Vol. 30, No. 10, 2011, pp. 1587-1597. doi:10.1016/j.trac.2011.08.006

[130] R. Stoltenburg, C. Reinemann and B. Strehlitz, "SELEXA(r)evolutionary Method to Generate High-Affinity Nucleic Acid Ligands,” Biomolecular Engineering, Vol. 24, No. 4, 2007, pp. 381-403. doi:10.1016/j.bioeng.2007.06.001

[131] A. Famulok and J. W. Szostak, "In Vitro Selection of Specific Ligand Binding Nucleic Acids,” Angewandte Chemie-International Edition, Vol. 31, No. 8, 1992, pp. 979988. doi:10.1002/anie.199209791

[132] S. D. Jayasena, “Aptamers: An Emerging Class of Molecules That Rival Antibodies in Diagnostics," Clinical Chemistry, Vol. 45, No. 9, 1999, pp. 1628-1650.

[133] A. Sassolas, L. J. Blum and B. D. Leca-Bouvier, "Optical Detection Systems Using Immobilized Aptamers,” Biosensors and Bioelectronics, Vol. 26, No. 9, 2011, pp. 37253736. doi:10.1016/j.bios.2011.02.031

[134] A. Sassolas, L. J. Blum and B. D. Leca-Bouvier, "Electrochemical Aptasensors,” Electroanalysis, Vol. 21, 2009, pp. 1237-1250. doi:10.1002/elan.200804554

[135] T. Yuan, Z.-Y. Liu, L.-Z. Hu and G.-B. Xu, "Electrochemical and Electrochemiluminescent Aptasensors," Chinese Journal of Analytical Chemistry, Vol. 39, No. 7, 2011, pp. 972-977. doi:10.1016/S1872-2040(10)60451-3

[136] A.-E. Radi, "Electrochemical Aptamer-Based Biosensors: Recent Advances and Perspectives,” International Journal of Electrochemistry, 2011, Article ID 863196.

[137] Y. Xu, G. Cheng, P. He and Y. Fang, “A Review: Electrochemical Aptasensors with Various Detection Strategies,” Electroanalysis, Vol. 21, No. 11, 2009, pp. 12511259. doi:10.1002/elan.200804561

[138] J. He, Y. Liu, M. Fan and X. Liu, "Isolation and Identification of the Dna Aptamer Target to Acetamiprid," Journal of Agricultural and Food Chemistry, Vol. 59, No. 5, 2011, pp. 1582-1586. doi:10.1021/jf104189g
[139] A. L. Hillberg, K. R. Brain and C. J. Allender, "Molecular imprinted Polymer Sensors: Implications for Therapeutics," Advanced Drug Delivery Reviews, Vol. 57, No. 12, 2005, pp. 1875-1889. doi:10.1016/j.addr.2005.07.016

[140] A. G. Mayes and M. J. Whitcombe, "Synthetic Strategies for the Generation of Molecularly Imprinted Organic Polymers," Advanced Drug Delivery Reviews, Vol. 57, No. 12, 2005, pp. 1742-1778. doi:10.1016/j.addr.2005.07.011

[141] V. Pichon and F. Chapuis-Hugon, "Role of Molecularly Imprinted Polymers for Selective Determination of Environmental Pollutants-A Review," Analytica Chimica Acta, Vol. 622, No. 1-2, 2008, pp. 48-61. doi:10.1016/j.aca.2008.05.057

[142] A. L. Jenkins, R. Yin and J. L. Jensen, "Molecularly Imprinted Polymer Sensors for Pesticide and Insecticide Detection in Water," Analyst, Vol. 126, 2001, pp. 798802. doi:10.1039/b008853f

[143] C. Xie, S. Gao, Q. Guo and K. Xu, "Electrochemical Sensor for 2,4-Dichlorophenoxy Acetic Acid Using Molecularly Imprinted Polypyrrole Membrane as Recognition Element," Microchimica Acta, Vol. 169, No. 1, 2010, pp. 145- 152. doi:10.1007/s00604-010-0303-7

[144] C. Pellicer, A. Gomez-Caballero, N. Unceta, M. A. Goicolea and R. J. Barrio, "Using a Portable Device Based on Screen-Printed Sensor Modified with a Molecularly Imprinted Polymer for the Determination of the Insecticide Fenitrothion in Forest Samples," Analytical Methods, Vol. 2, No. 9, 2010, pp. 1280-1285. doi:10.1039/c0ay00329h

[145] E. Pardieu, H. Cheap, C. Vedrine, M. Lazerges, Y. Lattach, F. Garnier, S. remira and C. Pernelle, "Molecularly Imprinted Conducting Polymer Based Electrochemical Sensor for Detection of Atrazine," Analytica Chimica Acta, Vol. 649, No. 2, 2009, pp. 236-245. doi:10.1016/j.aca.2009.07.029

[146] M. Cortina-Puig, G. Istamboulie, T. Noguer and J. L. Marty, "Analysis of Pesticide Mixtures Using Intelligent Biosensors,” In: V. S. Somerset, Ed., Intelligent and Biosensors, 2010, pp. 205-216.

[147] G. Istamboulie, M. Cortina-Puig, J. L. Marty and T. Noguer, "The Use of Artificial Neural Networks for the Selective Detection of Two Organophosphate Insecticides: Chlorpyrifos and Chlorfenvinfos,” Talanta, Vol. 79, No. 2, 2009, pp. 507-511. doi:10.1016/j.talanta.2009.04.014

[148] X. Zhang, Q. Guo and D. Cui, "Recent Advances in Nanotechnology Applied to Biosensors,” Sensors, Vol. 9, No. 2, 2009, pp. 1033-1053. doi:10.3390/s90201033

[149] R. Singh, "Prospects of Nanobiomaterials for Biosensing,” International Journal of Electrochemistry, 2011, Article ID 125487.

[150] A. Ballesteros-Gomez and S. Rubio, "Recent Advances in Environmental Analysis,” Analytical Chemistry, Vol. 81, No. 12, 2009, pp. 4601-4622. doi:10.1021/ac200921j

[151] A. Sassolas, L. J. Blum and B. D. Leca-Bouvier, "Immobilization Strategies to Develop Enzymatic Biosensors," Biotechnology Advances, in press, doi:10.1016/j.biotechadv.2011.09.003

[152] X.-H. Li, Z. Xie, H. Min, C. Li, M. Liu and Y. J. Xian, "Development of Quantum Dots Modified Acetylcholi- 
nesterase Biosensor for the Detection of Trichlorfon,” Electroanalysis, Vol. 18, No. 22, 2006, pp. 2163-2167. doi:10.1002/elan.200603615

[153] J. Pingarron, P. Yanez-Sedeno and A. Gonzalez-Cortes, "Gold Nanoparticles-Based Electrochemical Biosensors," Electrochimica Acta, Vol. 53, No. 19, 2008, pp. 58485866. doi:10.1016/j.electacta.2008.03.005

[154] D. Du, S. Chen, J. Cai and A. Zhang, "Electrochemical Pesticide Sensitivity Test Using Acetylcholinesterase Biosensor Based on Colloidal Gold Nanoparticle Modified Sol-Gel Interface,” Talanta, Vol. 74, No. 4, 2008, pp. 766-772. doi:10.1016/j.talanta.2007.07.014

[155] D. Du, S. Chen, D. Song, H. Li and X. Chen, "Development of Acetylcholinesterase Biosensor Based on CdTe Quantum Dots/Gold Nanoparticles Modified Chitosan Microspheres Interface,” Biosensors and Bioelectronics, Vol. 24, No. 3, 2008, pp. 475-479. doi:10.1016/j.bios.2008.05.005

[156] P. Sharma, K. Sablok, V. Bhalla and C. R. Suri, “A Novel Disposable Electrochemical Immunosensor for Phenyl Urea Herbicide Diuron,” Biosensors and Bioelectronics, Vol. 26, No. 10, 2011, pp. 4209-4212. doi:10.1016/j.bios.2011.03.019

[157] T.-J. Lin, K.-T. Huang and C.-Y. Liu, "Determination of Organophosphorous Pesticides by a Novel Biosensor Based on Localized Surface Plasmon Resonance," Biosensors and Bioelectronics, Vol. 22, No. 4, 2006, pp. 513-518. doi:10.1016/j.bios.2006.05.007

[158] X. Sun, B. Liu and K. Xia, “A Sensitive and Regenerable Biosensor for Organophosphate Pesticide Based on SelfAssembled Multilayer Film with CdTe as Fluorescence Probe,” Luminescence, Vol. 26, No. 6, 2011, pp. 616-621. doi:10.1002/bio.1284

[159] J. Fu, B. PArk and Y. Zhao, "Limitation of a Localized Surface Plasmon Resonance Sensor for Salmonella Detection,” Sensors and Actuators B, Vol. 141, No. 1, 2009, pp. 276-283. doi:10.1016/j.snb.2009.06.020

[160] L.-K. Chau, Y.-F. Lin, S.-F. Cheng and T.-J. Lin, "Fiber-Optic Chemical and Biochemical Probes Based on Localized Surface Plasmon Resonance," Sensors and Actuators B, Vol. 113, No. 1, 2006, pp. 100-105. doi:10.1016/j.snb.2005.02.034

[161] J. Wang, "Carbon-Nanotube Based Electrochemical Biosensors: A Review,” Electroanalysis, Vol. 17, No. 1, 2005, pp. 7-14. doi:10.1002/elan.200403113

[162] D. Du, X. Huang, J. Cai and A. Zhang, "Comparison of Pesticide Sensitivity by Electrochemical Test Based on Acetylcholinesterase Biosensor," Biosensors and Bioelectronics, Vol. 23, No. 2, 2007, pp. 285-289. doi:10.1016/j.bios.2007.05.002

[163] A. C. Oliveira and L. H. Mascaro, "Evaluation of Acetylcholinesterase Biosensor Based on Carbon Nanotube Paste in the Determination of Chlorphenvinphos," International Journal of Analytical Chemistry, 2011, Article ID 974216. doi:10.1155/2011/974216

[164] S. Firdoz, F. Ma, X. Yue, Z. Dai, A. Kumar and B. Jiang, "A Novel Amperometric Biosensor Based on Single Walled Carbon Nanotubes with Acetylcholine Esterase for the Detection of Carbaryl Pestcide in Water,” Talanta, Vol.
83, No. 1, 2010, pp. 269-273. doi:10.1016/j.talanta.2010.09.028

[165] Y. Qu, Q. Sun, F. Xiao, G. Shi and L. Jin, "Layerby-Layer Self-Assembled Acetylcholienesterase/ PAMAMAu on CNTs Modified Electrode for Sensing Pesticides," Bioelectrochemistry, Vol. 77, No. 2, 2010, pp. 139-144. doi:10.1016/j.bioelechem.2009.08.001

[166] S. Chen, J. Huang, D. Du, J. Li, H. Tu, D. Liu and A. Zhang, "Methyl Parathion Hydrolase Based Nanocomposite Biosensors for Highly Sensitive and Selective Determination of Methyl Parathion," Biosensors and Bioelectronics, Vol. 26, No. 11, 2011, pp. 4320-4325. doi:10.1016/j.bios.2011.04.025

[167] J. L. Marty, B. Leca and T. Noguer, "Biosensors for the Detection of Pesticides,” Analusis Magazine, Vol. 26, 1998, pp. 144-149. doi:10.1051/analusis:199826060144

[168] M. Blanco-Lopez, "Electrochemical Sensors Ased on Molecularly Imprinted Polymers," Trends in Analytical Chemistry, Vol. 23, No. 1, 2004, pp. 36-48. doi:10.1016/S0165-9936(04)00102-5

[169] S. A. Piletsky and A. P. F. Turner, "Electrochemical Sensors Based on Molecularly Imprinted Polymers," Electroanalysis, Vol. 14, No. 5, 2002, pp. 317-323. doi:10.1002/1521-4109

[170] A. C. Ion, I. Ion, A. Culetu, D. Gherase, C. A. Moldovan, R. Iosub and A. Dinescu, "Acetylcholinesterase Voltammetric Biosensors Based on Carbon Nanostructure-Chitosan Composite Material for Organophosphate Pesticides,” Materials Science and Engineering, Vol. 30, No. 6, 2010, pp. 817-821. doi:10.1016/j.msec.2010.03.017

[171] S. Viswanathan, H. Radecka and J. Radecki, "Electrochemical Biosensor for Pesticides Based on Acetylcholinesterase Immobilized on Polyaniline Deposited on Vertically Assembled Carbon Nanotubes Wrapped with ssDNA," Biosensors and Bioelectronics, Vol. 24, No. 9, 2009, pp. 2772-2777. doi:10.1016/j.bios.2009.01.044

[172] N. Chauhan, J. Narang and C. S. Pundir, "Immobilization of Rat Brain Acetylcholinesterase on ZnS and Poly(Indole-5-carboxylic acid) Modified Au Electrode for Detection of Organophosphorus Insecticides,” Biosensors and Bioelectronics, Vol. 29, No. 1, 2011, pp. 82-88. doi:10.1016/j.bios.2011.07.070

[173] G. Istamboulie, T. Sikora, E. Jubete, E. Ochoteco, J. L. Marty and T. Noguer, "Screen-Printed Poly(3,4-Ethylenedioxythiophene) (PEDOT): A New Electrochemical Mediator for Acetylcholinesterase-Based Biosensors,” Talanta, Vol. 82, No. 3, 2010, pp. 957-961. doi:10.1016/j.talanta.2010.05.070

[174] A. Hildebrandt, J. Ribas, R. Bragos, J. L. Marty, M. Tresanchez and S. Lacorte, "Development of a Portable Biosensor for Screening Neurotoxic Agents in Water Samples,” Talanta, Vol. 75, No. 5, 2008, pp. 1208-1213. doi:10.1016/j.talanta.2008.01.033

[175] A. Hildebrandt, R. Bragos, S. Lacorte and J. L. Marty, "Performance of a Portable Biosensor for the Analysis of Organophosphorus and Carbamate Insecticides in Water and Food,” Sensors and Actuators B, Vol. 133, No. 1, 2010, pp. 195-201. doi:10.1016/j.snb.2008.02.017 
[176] Y. Ivanov, I. Marinov, K. Gabrovska, N. Dimcheva and T. Godjevargova, “Amperometric Biosensor Based on a SiteSpecific Immobilization of Acetylcholinesterase via Affinity Bonds on a Nanostructured Polymer Membrane With Intergrated Multiwall Carbon Nanotubes," Journal of Molecular Catalysis B: Enzymatic, Vol. 63, No. 3-4, 2010, pp. 141-148. doi:10.1016/j.molcatb.2010.01.005

[177] R. Sinha, M. Ganesana, S. Andreescu and L. Stanciu, "AChE Biosensor Based on Zinc Oxide Sol-Gel for the Detection of Pesticides,” Analytica Chimica Acta, Vol. 661, No. 2, 2010, pp. 195-199. doi:10.1016/j.aca.2009.12.020

[178] Y. Wang, S. Zhang, D. Du, Y. Shao, Z. Li, J. Wang, M. H. Englehard, J. Li and Y. H. Lin, "Self Assembly of Acetylcholinesterase on a Gold Nanoparticles-Graphene Nanosheet Hybrid for Organophosphate Pesticide Detection Using Polyelectrolyte as a Linker,” Journal of Materials Chemitsry, Vol. 21, No. 22, 2011, pp. 5319-5325.

[179] F. Arduini, F. Ricci, C. S. Tuta, D. Moscone, A. Amine and G. Palleschi, "Detection of Carbamic and Organophosphorous Pesticides in Water Samples Using a Cholinesterase Biosensor Based on Prussian Blue-Modified Screen-Printed Electrode," Analytica Chimica Acta, Vol. 580, No. 2, 2006, pp. 155-162. doi:10.1016/j.aca.2006.07.052

[180] G. Valdes-Ramirez, M. Cortina, M. T. Ramirez-Silva and J. L. Marty, "Acetylcholinesterase-Based Biosensors for Quantification of Carbofuran, Methylparaoxon, and Dichlorvos in 5\% Acetonitrile," Analytical and Bioanalytical Chemistry, Vol. 392, No. 4, 2008, pp. 699-707. doi:10.1007/s00216-008-2290-7

[181] D. Du, X. Huang, J. Cai and A. Zhang, “Amperometric Detection of Triazophos Pesticide Using Acetylcholinesterase Biosensor Based on Miltiwall Carbon Nanotube-Chitosan Matrix,” Sensors and Actuators B, Vol. 127, No. 2, 2007, pp. 531-535. doi:10.1016/j.snb.2007.05.006

[182] A. Vakurov, C. E. Simpson, C. L. Daly, T. D. Gibson and P. A. Millner, “Acetylcholinesterase-Based Biosensor Electrodes for Organophosphate Pesticide Detection. I. Modification of Carbon Surface for Immobilization of Acetylcholinesterase," Biosensors and Bioelectronics, Vol. 20, No. 6, 2004, pp. 1118-1125. doi:10.1016/j.bios.2004.03.039

[183] S. Sotiropoulou, D. Fournier and N. A. Chaniotakis, "Genetically Engineered Acetylcholinesterase-Based Biosensor for Attomolar Detection of Dichlorvos,” Biosensors and Bioelectronics, Vol. 20, No. 11, 2005, pp. 2347-2352. doi:10.1016/j.bios.2004.08.026

[184] X. Sun and X. Wang, “Acetylcholinesterase Biosensor Based on Prussian Blue-Modified Electrode for Detecting Organophosphorous Pesticides," Biosensors and Bioelectronics, Vol. 25, No. 1-2, 2010, pp. 2611-2614. doi:10.1016/j.bios.2010.04.028

[185] Y. Wei, Y. Li, Y. Qu, F. Xiao, G. Shi and L. Jin, “A Novel Biosensor Based on Photoelectro-Synergistic Catalysis for Flow-Injection Analysis System/Amperometric Detection of Organophosphorous Pesticides," Analytica Chimica Acta, Vol. 643, No. 1-2, 2009, pp. 13-18. doi:10.1016/j.aca.2009.03.045
[186] D. Du, S. Chen, J. Cai and A. Zhang, “Immobilization of Acetylcholinesterase on Gold Nanoparticles Embedded in Sol-Gel Film for Amperometric Detection of Organophosphorous,” Biosensors and Bioelectronics, Vol. 23, No. 1, 2007, pp. 130-134. doi:10.1016/j.bios.2007.03.008

[187] A. Ishii, S. Takeda, S. Hattori, K. Sueoka and K. Mukasa, "Ultrasensitive Detection of Organophosphate Insecticides by Carbon Field-Effect Transistor," Colloids and Surfaces A, Vol. 313-314, 2008, pp. 456-460.

[188] N. Gan, X. Yang, D. Xie, Y. Wu and W. Wen, “A Disposable Organophosphorus Pesticides Enzyme Biosensor Based On Magnetic Nano-Particles Modified Screen Printed Carbon Electrode,” Sensors, Vol. 10, No. 1, 2010, pp. 665-638. doi:10.3390/s100100625

[189] D. Du, J. Ding, J. Cai and A. Zhang, “Determination of Carbaryl Pesticide Using Amperometric Acetylcholinesterase Sensor Formed by Electrochemically Deposited Chitosan," Colloids and Surfaces B Biointerfaces, Vol. 58, No. 1, 2007, pp. 145-150. doi:10.1016/j.colsurfb.2007.03.006

[190] S. P. Zhang, L. G. Shan, Z. R. Tian, Y. Zheng, L. Y. Shi and D. S. Zhang, "Study of Enzyme Biosensor Based on Carbon Nanotubes Modified Electrode for Detection of Pesticides Residue," Chinese Chemical Letters, Vol. 19, No. 5, 2008, pp. 592-594._doi:10.1016/j.cclet.2008.03.014

[191] Y. Qu, Q. Sun, F. Xiao, G. Shi and L. Jin, "Layerby-Layer Self-Assembled Acetylcholinesterase/PAMAM$\mathrm{Au}$ on CNTs Modified Electrode for Sensing Pesticides," Bioelectrochemistry, Vol. 77, No. 2, 2010, pp. 139-144. doi:10.1016/j.bioelechem.2009.08.001

[192] S. Laschi, D. Ogonczyk, I. Palchetti and M. Mascini, "Evaluation of Pesticide-Induced Acetylcholinesterase Inhibition by Means of Disposable Carbon-Modiifed Electrochemical Biosensors,” Enzyme and Microbial Technology, Vol. 40, No. 3, 2007, pp. 485-489. doi:10.1016/j.enzmictec.2006.08.004

[193] S. Sajjadi, H. Ghourchian and H. Tavakoli, "Choline Oxidase as a Selective Recognition Element for Determination of Paraoxon," Biosensors and Bioelectronics, Vol. 24, No. 8, 2009, pp. 2509-2514. doi:10.1016/j.bios.2009.01.008

[194] R. P. Deo, J. Wang, I. Block, A. Mulchandani, K. A. Joshi, M. Trojanowicz, F. Scholz, W. Chen and Y. H. Lin, "Determination of Organophosphate Pesticides at a Carbon Nanotube/Organophosphorus Hydrolase Electrochemical biosensor," Analytica Chimica Acta, Vol. 530, No. 2, 2005, pp. 185-189. doi:10.1016/j.aca.2004.09.072

[195] T. Laothanachareon, V. Champreda, P. Sritongkham, M. Somasundrum and W. Surareungchai, "Cross-Linked Enzyme Crystals of Organophosphate Hydrolase for Electrochemical Detection of Organophosphorus Compounds," World Journal of Microbiology and Biotechnology, Vol. 24, No. 12, 2008, pp. 3049-3055. doi:10.1007/s11274-008-9851-yOpen

[196] A. Mulchandani, S. T. Pan and W. Chen, "Fiber-Optic Enzyme Biosensor for Direct Determination of Organophosphate Nerve Agents,” Biotechnology Progress, Vol. 15, No. 1, 1999, pp. 130-134. doi:10.1021/bp980111q

[197] V. Sacks, I. Eshkenazi, T. Neufeld, C. Dosoretz and J. Rishpon, "Immobilized Parathion Hydrolase: An Am- 
perometric Sensor for Parathion,” Analytical Chemistry, Vol. 72, No. 9, 2000, pp. 2055-2058.

doi:10.1021/ac9911488

[198] L. Viveros, S. Paliwal, D. McCrae, J. Wild and A. Simonian, "A Fluorescence-Based Biosensor for the Detection of Organophosphate Pesticides and Chemical Warfare Agents," Sensors and Actuators B, Vol. 115, No. 1, 2006, pp. 150-157. doi:10.1016/j.snb.2005.08.032

[199] K. A. Fähnrich, M. Pacda and G. G. Guilbault, “Diposable Amperometric Immunosensor for the Detection of Polycyclic Aromatic Hydrocarbons (PAHs) Using ScreenPrinted Electrodes," Biosensors and Bioelectronics, Vol. 18, No. 1, 2003, pp. 73-82. doi:10.1016/S0956-5663(02)00112-4

[200] S.-Q. Hu, J.-W. Xie, Q.-H. Xu, K. T. Rong, G.-L. Shen and R.-Q. Yu, "A Label-Free Electrochemical Immunosensor Based on Gold Nanoparticles for Detection of Paraoxon,” Talanta, Vol. 61, No. 6, 2003, pp. 769-777. doi:10.1016/S0039-9140(03)00368-0

[201] E. Zacco, R. Galve, M. P. Marco, S. Alegret and M. I. Pividori, "Electrochemical Biosensing of Pesticide Residues Based on Affinity Biocomposite Platforms," Biosensors and Bioelectronics, Vol. 22, No. 8, 2007, pp. 17071715. doi:10.1016/j.bios.2006.07.037

[202] D. Butler and G. G. Guilbault, "Disposable Amperometric Immunosensor for the Detection of $17-\beta$ Estradiol Using Screen-Printed Electrodes," Sensors and Actuators B, Vol. 113, No. 2, 2006, pp. 692-699. doi:10.1016/j.snb.2005.07.019

[203] L. Chen, G. Zeng, Y. Zhang, L. Tang, D. Huang, C. Liu, Y. Pang and J. Luo, "Trace Detection of Pichloram Using an Electrochemical Immunosensor Based on 3D Au Nanoclusters," Analytical Biochemistry, Vol. 407, No. 2, 2010, pp. 172-179. doi:10.1016/j.ab.2010.08.001

[204] Y. Zhang and H.-S. Zhuang, “Amperometric Immunosensor Based on Layer-by-Layer Assembly of Thiourea and Nano-Gold Particles on Gold Electrode for Determination of Naphthalene," Chinese Journal of Analytical Chemistry, Vol. 38, No. 2, 2010, pp. 153-157. doi:10.1016/S1872-2040(09)60021-9

[205] I. Navratilova and P. Skladal, “The Immunosensors for Measurement of 2,4-Dichlorophenoxyacetic Acid Based on Electrochemical Impedance Spectroscopy,” Bioelectrochemistry, Vol. 62, No. 1, 2004, pp. 11-18. doi:10.1016/j.bioelechem.2003.10.004

[206] M. F. Gouzy, M. Kess and P. M. Kramer, “A SPR-Based Immunosensor for the Detection of Isoproturon,” Biosensors and Bioelectronics, Vol. 24, No. 6, 2009, pp. 1563-1568. doi:10.1016/j.bios.2008.08.005

[207] D. R. Shankaran, K. Matsumoto, K. Toko and N. Miura, "Development and Comparison of Two Immunoassays for the Detection of 2,4,6-Trinitrotoluene (TNT) Based on Surface Plasmon Resonance," Sensors and Actuators B, Vol. 114, No. 1, 2006, pp. 71-79. doi:10.1016/j.snb.2005.04.013

[208] T. Kawaguchi, D. R. Shankaran, G. Y. Kim, K. Matsumoto, K. Toko and N. Miura, "Surface Plasmon Resonance Au Nanoparticle for Detection of TNT," Sensors and Actuators B, Vol. 133, No. 2, 2008, pp. 467-472. doi:10.1016/j.snb.2008.03.005

[209] T. Kawaguchi, D. R. Shankaran, S. J. Kim, K. V. Gobi, K. Matsumoto, K. Toko and N. Miura, "Fabrication of a Novel Immunosensor Using Functionalized Self-Assembled Monolayer for Trace Lavel Detection of TNT by Surface Plasmon Resonance,” Talanta, Vol. 72, No. 2, 2007, pp. 554-560. doi:10.1016/j.talanta.2006.11.020

[210] P. Singh, T. Onodera, Y. Mizuta, K. Matsumoto, N. Miura and K. Toko, "Dendrimer Modified Biochip for Detection of 2,4,6 Trinitrotoluene on SPR Immunosensor: Fabrication and Advantages," Sensors and Actuators B, Vol. 137, No. 2, 2009, pp. 403-409. doi:10.1016/j.snb.2008.12.027

[211] K. Nagatomo, T. Kawaguchi, N. Miura, K. Toko and K. Matsumoto, "Development of a Sensitive Surface Plasmon Resonance Immunosensor for Detection of 2,4-Dinitrotoluene with a Novel Oligo (Ethylene Glycol)-Based Sensor Surface,” Talanta, Vol. 79, No. 4, 2009, pp. 1142 1148. doi:10.1016/j.talanta.2009.02.018

[212] N. Soh, T. Tokuda, T. Watanabe, K. Mishima, T. Imato, T. Masadome, Y. Asano, S. Okutani, O. Niwa and S. Brown, “A Surface Plasmon Resonance Immunosensor for Detecting a Dioxin Precursor Using a Gold Binding Polypeptide," Talanta, Vol. 60, No. 4, 2003, pp. 733-745. doi:10.1016/S0039-9140(03)00139-5 